\title{
Comparisons of stemflow and its bio-/abiotic influential factors between two xerophytic shrub species
}

\author{
Chuan Yuan ${ }^{1,2}$, Guangyao Gao ${ }^{1,3}$, and Bojie Fu ${ }^{1,3}$ \\ ${ }^{1}$ State Key Laboratory of Urban and Regional Ecology, Research Center for Eco-Environmental Sciences, \\ Chinese Academy of Sciences, Beijing 100085, China \\ ${ }^{2}$ University of Chinese Academy of Sciences, Beijing 100049, China \\ ${ }^{3}$ Joint Center for Global Change Studies, Beijing 100875, China \\ Correspondence to: Guangyao Gao (gygao@ rcees.ac.cn)
}

Received: 18 August 2016 - Discussion started: 31 August 2016

Revised: 16 February 2017 - Accepted: 24 February 2017 - Published: 9 March 2017

\begin{abstract}
Stemflow transports nutrient-enriched precipitation to the rhizosphere and functions as an efficient terrestrial flux in water-stressed ecosystems. However, its ecological significance has generally been underestimated because it is relatively limited in amount, and the biotic mechanisms that affect it have not been thoroughly studied at the leaf scale. This study was conducted during the 2014 and 2015 rainy seasons at the northern Loess Plateau of China. We measured the branch stemflow volume $\left(\mathrm{SF}_{\mathrm{b}}\right)$, shrub stemflow equivalent water depth $\left(\mathrm{SF}_{\mathrm{d}}\right)$, stemflow percentage of incident precipitation (SF\%), stemflow productivity (SFP), funnelling ratio (FR), the meteorological characteristics and the plant traits of branches and leaves of C. korshinskii and S. psammophila. This study evaluated stemflow efficiency for the first time with the combined results of SFP and FR, and sought to determine the inter- and intra-specific differences of stemflow yield and efficiency between the two species, as well as the specific bio-/abiotic mechanisms that affected stemflow. The results indicated that $C$. korshinskii had a greater stemflow yield and efficiency at all precipitation levels than that of S. psammophila. The largest inter-specific difference generally occurred at the $5-10 \mathrm{~mm}$ branches during rains of $\leq 2 \mathrm{~mm}$. Precipitation amount was the most influential meteorological characteristic that affected stemflow yield and efficiency in these two endemic shrub species. Branch angle was the most influential plant trait on FR. For SF biomass and leaf biomass were the most influential plant traits for C. korshinskii and S. psammophila, respectively. For SFP of these two shrub species, leaf traits (the individual leaf area) and branch traits (branch size and biomass allocation
\end{abstract}

pattern) had a great influence during lighter rains $\leq 10 \mathrm{~mm}$ and heavier rains $>15 \mathrm{~mm}$, respectively. The lower precipitation threshold to start stemflow allowed C. korshinskii $(0.9 \mathrm{~mm}$ vs. $2.1 \mathrm{~mm}$ for $S$. psammophila) to employ more rains to harvest water via stemflow. The beneficial leaf traits (e.g., leaf shape, arrangement, area, amount) might partly explain the greater stemflow production of $C$. korshinskii. Comparison of $\mathrm{SF}_{\mathrm{b}}$ between the foliated and manually defoliated shrubs during the 2015 rainy season indicated that the newly exposed branch surface at the defoliated period and the resulting rainfall intercepting effects might be an important mechanism affecting stemflow in the dormant season.

\section{Introduction}

Stemflow delivers precipitation to the plant root zone more efficiently via preferential root paths, worm paths and soil macropores, compared with throughfall, another important element of rainfall redistribution. The double-funnelling effects of stemflow and preferential flow create "hot spots" and "hot moments" by enhancing nutrient cycling rates at the surface soil matrix (Mcclain et al., 2003; Johnson and Lehmann, 2006; Sponseller, 2007), thus substantially contributing to the formation and maintenance of "fertile islands" (Whitford et al., 1997), "resource islands" (Reynolds et al., 1999) or "hydrologic islands" (Rango et al., 2006). This effect is important for the normal function of rainfed dryland ecosystems (Wang et al., 2011). 
Shrubs are the representative plant functional type (PFT) in dryland ecosystems. They have developed effective physiological drought tolerance by reducing water loss, e.g., through adjusting their photosynthetic and transpiration rate by regulating stomatal conductance and abscisic acid (ABA), titling their osmotic equilibrium by regulating the concentration of soluble sugars and inorganic ions, and removing free radicals (Ma et al., 2004, 2008). The stemflow, a vital ecohydrological flux, is involved in replenishing soil water at shallow and deep layers (Pressland, 1973), particularly the root zone (Whitford et al., 1997; Dunkerley, 2000; Yang, 2010), even during light rains ( $\mathrm{Li}$ et al., 2009). It might allow the endemic shrubs to remain physically active during drought spells (Navar and Bryan, 1990; Navar, 2011). The stemflow is an important potential source for available water at rainfed dryland ecosystem (Li et al., 2013). Therefore, producing stemflow with a greater amount in a more efficient manner might be an effective strategy to utilize precipitation by reducing the evaporation loss (Devitt and Smith, 2002; Li et al., 2009), acquire water (Murakami, 2009) and withstand drought (Martinez-Meza and Whitford, 1996). However, because stemflow occurs in a small amount, some studies neglected the dynamics of stemflow yield by setting a fixed percentage of incident precipitation in the range of 1$8 \%$ (Dykes, 1997; Germer et al., 2006; Hagy et al., 2006) or even ignored stemflow while computing the water balance of terrestrial ecosystems (Llorens and Domingo, 2007; Zhang et al., 2016). That underestimated its disproportionately high influence on xerophytic shrub species (Andersson, 1991; Levia and Frost, 2003; Li, 2011). Therefore, it is important to quantify the inter- and intra-specific stemflow yield, to assess the stemflow production efficiency and to elucidate the underlying bio-/abiotic mechanisms.

Stemflow yield includes the stemflow volume and depth, and it describes the total flux delivered down to the base of a branch or a trunk. However, stemflow data are unavailable for comparison of inter-specific differences caused by variations in the branch architecture, the canopy structure, the shrub species and the ecozone. Herwitz (1986) introduced the funnelling ratio (FR), which expressed as the quotient of the volume of stemflow yield and the product of the base area and the precipitation amount. It indicates the efficiency with which individual branches or shrubs capture raindrops and deliver the water to the root zone (Siegert and Levia, 2014). The FR allows for a comparison of the inter- and intraspecific stemflow yield under different precipitation conditions. However, the FR does not provide a good connection between hydrological processes (e.g., rainfall redistribution) and the plant growth processes (e.g., biomass accumulation and allocation). Recently, Yuan et al. (2016) introduced the parameter of stemflow productivity (SFP), expressed as the volume of stemflow yield per unit of branch biomass. The SFP describes the efficiency by comparing the stemflow yield of unit biomass increment at different sized branches. Hence, it is necessary to combine the results of stemflow volume, depth, percentage of incident precipitation, FR and SFP for a comprehensive description of the inter- and intra-specific stemflow yield and efficiency at branch and shrub scales.

The precipitation amount has been generally recognized as the single most influential rainfall characteristic affecting stemflow production (Clements, 1972; André et al., 2008; Van Stan II et al., 2014). However, as to biotic mechanisms, although the canopy structure (Mauchamp and Janeau, 1993; Crockford and Richardson, 2000; Pypker et al., 2011) and branch architecture (Herwitz, 1987; Murakami, 2009; Carlyle-Moses and Schooling, 2015) have been studied for years, the most important plant traits vary with location and shrub species and have not yet been determined. The effects of the leaves have been studied more recently at a smaller scale, e.g., leaf orientation (Crockford and Richardson, 2000), shape (Xu et al., 2005), arrangement pattern (Owens et al., 2006), pubescence (Garcia-Estringana et al., 2010), area (Sellin et al., 2012), epidermis microrelief (RothNebelsick et al., 2012), amount (Li et al., 2016), or biomass (Yuan et al., 2016). Comparisons of stemflow yield during summer (the growing or foliated season) and winter (the dormant or defoliated season) generally indicate negative effects of leaves because more stemflow occurs during the leafless period (Dolman, 1987; Masukata et al., 1990; Neal et al., 1993; Mużyło et al., 2012). However, both negligible and positive effects have also been confirmed by Martinez-Meza and Whitford (1996), Deguchi et al. (2006) and Liang et al. (2009). The validity of these conflicting findings has been called into question as a result of the seasonal variation of meteorological conditions and plant traits, e.g., wind speed (André et al., 2008), rainfall intensity (Dunkerley, 2014a, b), air temperature and consequent precipitation type (snow-torain vs. snow) (Levia and Underwood, 2004). Moreover, they ignore the effects of the exposed stems at leafless period, which substitute the leaves to intercept raindrops and might play a significant role in stemflow production. Furthermore, although the rainfall simulator made an identical and gradient change of rainfall characteristics possible, the laboratory experiment ignored the dynamics of rainfall characteristics and meteorological features (e.g., wind speed, vapor pressure deficit, air temperature and humidity) during rainfall events at field conditions. Therefore, a controlled field experiment with the foliated and manually defoliated plants under the same stand conditions is needed to resolve these uncertainties.

In this study, the branch stemflow volume $\left(\mathrm{SF}_{\mathrm{b}}\right)$, the shrub stemflow depth $\left(\mathrm{SF}_{\mathrm{d}}\right)$, the stemflow percentage of the incident precipitation amount (SF \%), the SFP and the FR were measured in two xerophytic shrub species (C. korshinskii and S. psammophila) during the 2014 and 2015 rainy seasons. Furthermore, a controlled field experiment with foliated and manually defoliated shrubs was also conducted for the two shrub species during the 2015 rainy season. The detailed objectives were to (1) quantify the inter- and intra-specific stemflow yield $\left(\mathrm{SF}_{\mathrm{b}}, \mathrm{SF}_{\mathrm{d}}\right.$ and $\left.\mathrm{SF} \%\right)$ and efficiency (SFP and 

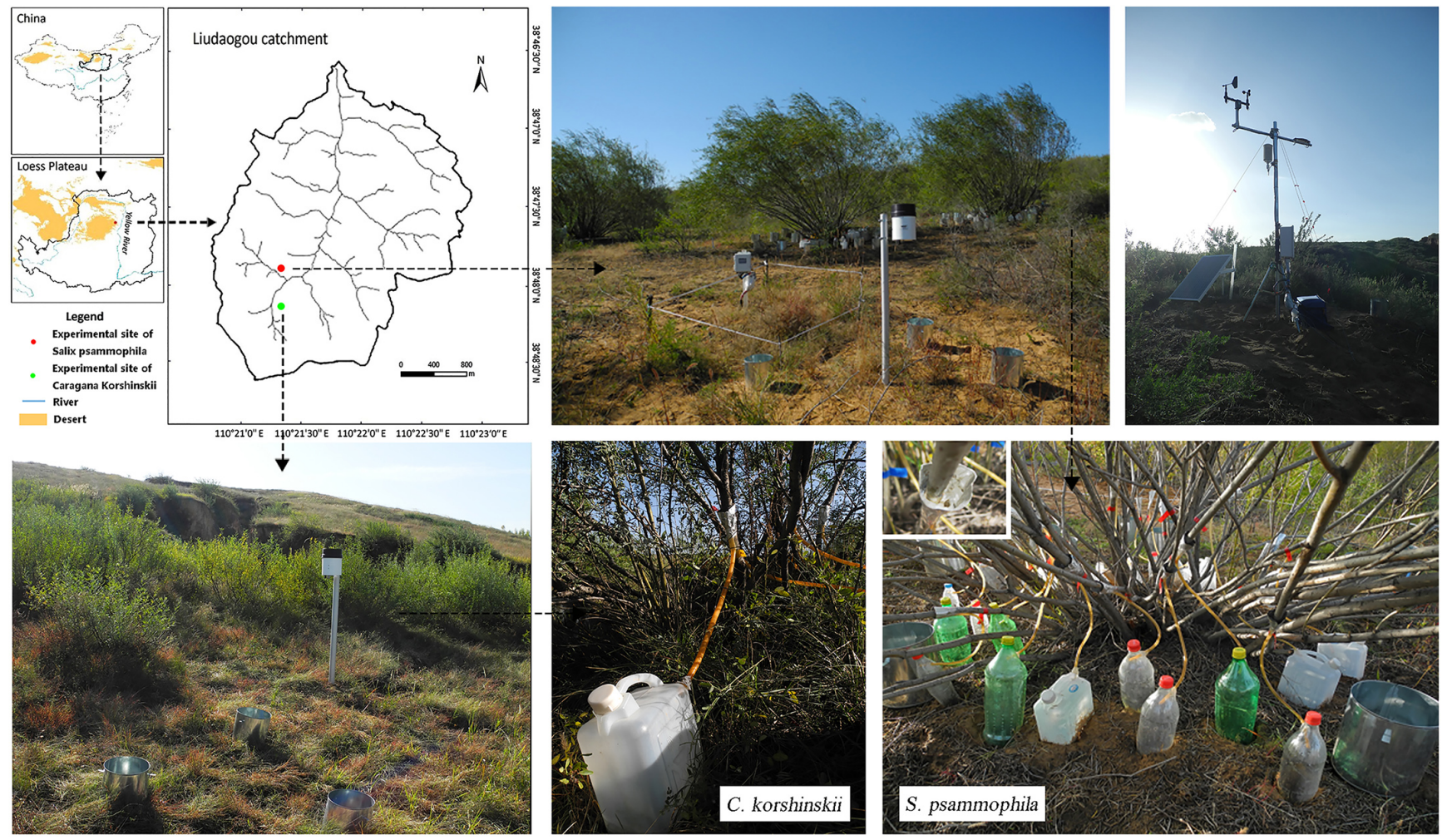

Figure 1. Location of the experimental stands and facilities for stemflow measurements of $C$. korshinskii and S. psammophila at the Liudaogou catchment in the Loess Plateau of China.

FR) at different precipitation levels; (2) identify the most influential meteorological characteristics affecting stemflow yield and (3) investigate the biotic influential mechanism of plant traits especially at the finer leaf scale. Given that only the aboveground ecohydrological process was involved, we focused on stemflow in this study, its interaction with soil moisture would be discussed in next study. The achievement of these research objectives would advance our understanding of the influential mechanism of stemflow production, its ecological importance for dryland shrubs, and the significance of leaves from an ecohydrological perspective.

\section{Materials and methods}

\subsection{Study area}

This study was conducted at the Liudaogou catchment $\left(110^{\circ} 21^{\prime}-110^{\circ} 23^{\prime} \mathrm{E}, 38^{\circ} 46^{\prime}-38^{\circ} 51^{\prime} \mathrm{N}\right)$ in Shenmu County in the Shaanxi Province of China. It is $6.9 \mathrm{~km}^{2}$ and 1094 $1273 \mathrm{~m}$ a.s.l. (above sea level). This area has a semiarid continental climate with well-defined rainy and dry seasons. The mean annual precipitation (MAP) between 1971 and 2013 is $414 \mathrm{~mm}$, with approximately $77 \%$ of the annual precipitation amount occurring from July to September (Jia et al., 2013). The potential evaporation is $1337 \mathrm{~mm} \mathrm{yr}^{-1}$, and the mean an- nual temperature is $9.0^{\circ} \mathrm{C}$ (Zhao et al., 2010). The coldest and warmest months are January and July, with an average monthly temperature of -9.7 and $23.7^{\circ} \mathrm{C}$, respectively. The two soil types Aeolian sandy soil and Ust-Sandiic Entisol dominate this catchment (Jia et al., 2011). Soil particles consist of $11.2-14.3 \%$ clay, $30.1-44.5 \%$ silt and $45.4-50.9 \%$ sand in terms of the soil classification system of United States Department of Agriculture (Zhu and Shao, 2008). The original plants are scarcely present, except for very few surviving shrub species, e.g., Ulmus macrocarpa, Xanthoceras sorbifolia, Rosa xanthina or Spiraea salicifolia. The currently predominant shrub species were planted decades ago, e.g., S. psammophila, C. Korshinskii or Amorpha fruticosa, and the predominant grass species include Medicago sativa, Stipa bungeana, Artemisia capillaris, Artemisia sacrorum, etc. (Ai et al., 2015).

Two representative experimental stands of C. Korshinskii and S. psammophila were established in the southwest of the Liudaogou catchment in this study (Fig. 1). As the endemic shrub species in arid and semiarid northern China, they were generally planted for wind proofing and dune stabilizing. Both C. korshinskii and S. psammophila are multi-stemmed shrubs that have an inverted cone canopy and no trunk, with the branches running obliquely from the base. $C$. korshinskii usually grows to $2 \mathrm{~m}$ and has pinnate compound leaves with 12-16 foliates in an opposite or sub-opposite arrangement 
(Wang et al., 2013). The leaf of $C$. korshinskii is concave and lanceolate shaped, with an acute leaf apex and an obtuse base. Both sides of the leaves are densely sericeous with appressed hairs (Liu et al., 2010). In comparison, S. psammophila usually grows to $3-4 \mathrm{~m}$, and has an odd number of strip shaped leaves with $2-4 \mathrm{~mm}$ in width and $40-80 \mathrm{~mm}$ in length. The young leaves are pubescent and gradually become subglabrous (Chao and Gong, 1999). These two shrub species were planted approximately 20 years ago, and the two stands shared a similar slope of $13-18^{\circ}$, a size of 3294 $4056 \mathrm{~m}^{2}$ and an elevation of 1179-1207 m a.s.l. However, the C. korshinskii experimental stand has a $224^{\circ}$ aspect with a loess ground surface, whereas the $S$. psammophila experimental stand has a $113^{\circ}$ aspect with a sand ground surface.

\subsection{Field experiments}

Field experiments were conducted during the rainy seasons of 2014 ( 1 July to 3 October) and 2015 (1 June to 30 September) to measure the meteorological characteristics, plant traits and stemflow. To avoid the effects of gully micro-geomorphology on meteorological recording, we installed an Onset ${ }^{\circledR}$ (Onset Computer Corp., Bourne, MA, USA) RG3-M tipping bucket rain gauge $(0.2 \mathrm{~mm}$ per tip) at each experimental stand. Three $20 \mathrm{~cm}$ diameter rain gauges were placed around to adjust the inherent underestimating of automatic precipitation recording (Groisman and Legates, 1994). Then, the rainfall characteristics, e.g., rainfall duration $(\mathrm{RD} ; \mathrm{h})$, rainfall interval $(\mathrm{RI} ; \mathrm{h})$, the average rainfall intensity $\left(I, \mathrm{~mm} \mathrm{~h}^{-1}\right)$, the maximum rainfall intensity in $5 \mathrm{~min}\left(I_{5}, \mathrm{~mm} \mathrm{~h}^{-1}\right), 10 \mathrm{~min}\left(I_{10}, \mathrm{~mm} \mathrm{~h}^{-1}\right)$ and $30 \mathrm{~min}\left(I_{30}, \mathrm{~mm} \mathrm{~h}^{-1}\right)$ could be calculated accordingly. In this study, the individual rainfall events were greater than $0.2 \mathrm{~mm}$ and separated by a period of at least $4 \mathrm{~h}$ without rain (Giacomin and Trucchi, 1992). Furthermore, a meteorological station was also installed at each experimental stand to record other meteorological characteristics (Fig. 1), e.g., wind speed (WS; $\mathrm{m} \mathrm{s}^{-1}$ ) and wind direction (WD; ${ }^{\circ}$ ) (Model 03002, R. M. Young Company, Traverse City, Michigan, USA), the air temperature $\left(T ;{ }^{\circ} \mathrm{C}\right)$ and humidity $(H ; \%)$ (Model HMP 155, Vaisala, Helsinki, Finland), and solar radiation (SR; $\mathrm{kW} \mathrm{m}^{-2}$ ) (Model CNR 4, Kipp \& Zonen B. V., Delft, the Netherlands). Moreover, raindrops attributes, including raindrop diameter $(D, \mathrm{~mm})$, raindrop terminal velocity $\left(V, \mathrm{~m} \mathrm{~s}^{-1}\right)$, and raindrop inclination angle from the vertical $\left(A,{ }^{\circ}\right)$, were also computed to investigate the possible effects of raindrop striking, the oblique and wind-driven rain on stemflow yield and efficiency.

C. korshinskii and S. psammophila, as modular organisms and multi-stemmed shrub species, have branches that seek their own survival goals and compete with each other for light and water (Firn, 2004; Allaby, 2010). They were ideal experiment objects to conduct a stemflow study at the branch scale. Therefore, we focused on branch stemflow and ignored the canopy variance by experimenting on sam- ple shrubs that had a similar canopy structure. Four mature shrubs were selected for C. korshinskii (designated as C1, $\mathrm{C} 2, \mathrm{C} 3$ and C4) and S. psammophila (designated as S1, S2, S3 and S4) for the stemflow measurements. They had isolated canopies, similar intra-specific canopy heights and areas, e.g., $2.1 \pm 0.2 \mathrm{~m}$ and $5.1 \pm 0.3 \mathrm{~m}^{2}$ for $\mathrm{C} 1-\mathrm{C} 4$, and $3.5 \pm 0.2 \mathrm{~m}$ and $21.4 \pm 5.2 \mathrm{~m}^{2}$ for $\mathrm{S} 1-\mathrm{S} 4$. We measured the morphological characteristics of all the 180 branches of $\mathrm{C} 1-$ $\mathrm{C} 4$ and all the 261 branches of S1-S4, including the branch basal diameter $(\mathrm{BD} ; \mathrm{mm})$, branch length $(\mathrm{BL} ; \mathrm{cm})$ and branch inclination angle $\left(\mathrm{BA} ;{ }^{\circ}\right)$. The leaf area index (LAI) and the foliage orientation (MTA, the mean tilt angle of leaves) were measured using the $\mathrm{LiCor}^{\circledR}$ (LiCor Biosciences Inc., Lincoln, NE, USA) 2200C plant canopy analyzer approximately twice a month.

A total of 53 branches of $C$. korshinskii $(17,21,7,8$ for the BD categories of 5-10, 10-15, 15-18 and $>18 \mathrm{~mm}$, respectively) and 98 branches of $S$. psammophila (20, 30, 20 and 28 branches at the BD categories of 5-10, 10-15, 15-18 and $>18 \mathrm{~mm}$, respectively) were selected for stemflow measurements following these criteria: (1) no intercrossing stems, (2) no turning point in height from branch tip to the base (Dong et al., 1987) and (3) representativeness in amount and branch size. Stemflow was collected using aluminum foil collars, which were more accurate than the spiral tubes because the tubes outlet were more liable to be blocked by vegetation litter (Wright, 1977; Durocher, 1990). The collar was fitted around the entire branch circumference and close to the branch base and sealed by neutral silicone caulking (Fig. 1). Nearly all sample branches were selected on the skirts of the crown, which were more convenient for installation and limited the amount of shading by other branches lying above. Associated with the limited external diameter of foil collars, they minimized the accessing of the precipitation and throughfall (both free and released). A $0.5 \mathrm{~cm}$ diameter PVC hose led the stemflow to lidded containers. The collars and hoses were checked periodically against any leakage and blockage. The stemflow was measured within $2 \mathrm{~h}$ after the rainfall ended during the daytime; if the rainfall ended at night, we took the measurement early the next morning. After completing measurements, we returned stemflow back to the branch base to mitigate the unnecessary drought stress for the sample branches. By doing so, we tried best to mitigate the influences of the precipitation and throughfall, which might lead to an overestimation of stemflow yield and efficiency. Nevertheless, these errors might not be eradicated at field conditions after all. The careful experiment practices were especially needed in this study, and more thoughtful experiment designs were required in future studies.

The controlled field experiment with foliated and manually defoliated shrubs was conducted during the 2015 rainy season for C. korshinskii (five rainfall events from 18 to 30 September) and for S. psammophila (10 rainfall events from 2 August to 30 September) (Fig. 2). Considering the workload to remove all the leaves of 85 branches on $C$. $k o$ - 

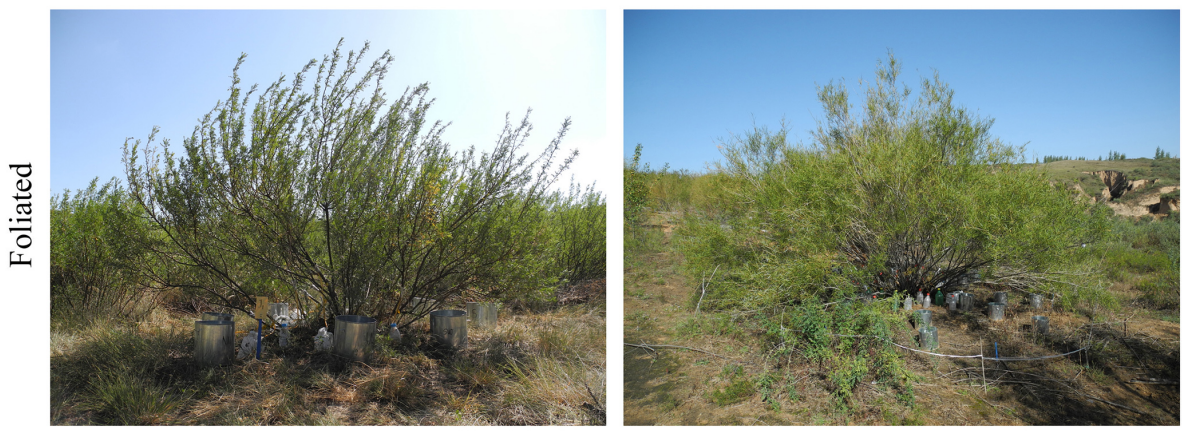

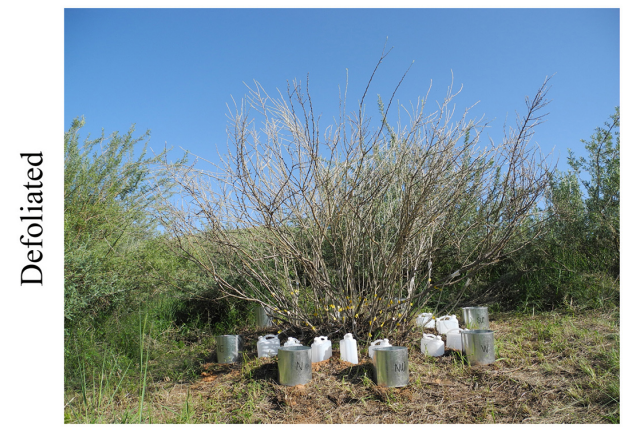

C. korshinskii

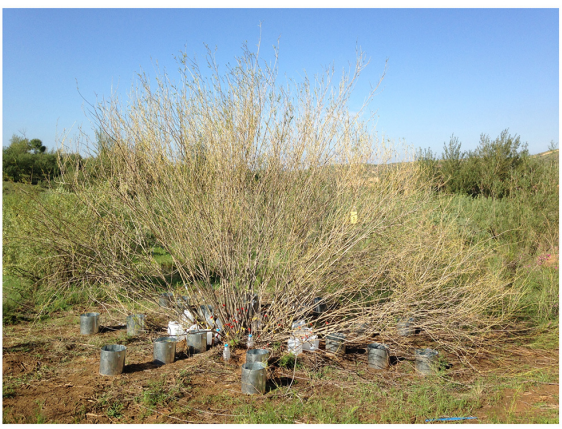

S. psammophila

Figure 2. The controlled field experiment for stemflow yield between the foliated and manually defoliated shrubs.

rshinskii (designated as C5) and 94 branches on S. psammophila (designated as S5) nearly twice a month, only one shrub individual was selected with similar intra-specific canopy height and area $\left(2.1 \mathrm{~m}\right.$ and $5.8 \mathrm{~m}^{2}$ for $\mathrm{C} 5,3.3 \mathrm{~m}$ and $19.9 \mathrm{~m}^{2}$ for S5) as other foliated experimental shrubs. A total of 10 branches of $\mathrm{C} 5$ (3, 3 and 4 branches at the BD categories 5-10, 10-15 and $>15 \mathrm{~mm}$ ), and 17 branches of S5 (4, 5 and 7 branches at the BD categories 5-10, 10-15 and $>15 \mathrm{~mm}$ ) were selected for stemflow measurements. According to the in situ measurement of branch morphology and the laboratory measurement of biomass, these sample branches had similar BD, BL, BA and biomass of leaves (BML) with those in the foliated shrubs $(\mathrm{C} 1-\mathrm{C} 4$ and $\mathrm{S} 1-$ S4) (see the values at Sect. 3.2). Given a limited amount of sample branches and rainfall events, the experimental results were just used for a comparison with those of the foliated shrubs, but not for a statistical analysis with meteorological characteristics and plant traits. If not specifically stated, it is important to notice that the stemflow yield and efficiency in this study referred to those of the foliated shrubs.

Another three shrubs of each species were destructively measured for biomass and leaf traits. They had similar canopy heights and areas as those of the shrubs for which the stemflow was measured, and were designated as C6-C8 (2.0-2.1 $\mathrm{m}$ and 5.8-6.8 $\left.\mathrm{m}^{2}\right)$ and S6-S8 (3.0-3.4 $\mathrm{m}$ and 15.4$19.2 \mathrm{~m}^{2}$ ). Therefore, the development of allometric models could be developed for estimating the corresponding biomass and leaf traits of C1-C5 and S1-S5 (Levia and Herwitz, 2005; Siles et al., 2010a, b; Stephenson et al., 2014). A total of 66 branches for C6-C8 and 61 branches for S6-S8 were measured once during mid-August for the biomass of leaves and stems (BML and BMS, g), the leaf area of the branches $\left(\mathrm{LAB}, \mathrm{cm}^{2}\right)$, and the leaf numbers of the branches (LNB), when the shrubs showed maximum vegetative growth. The BML and BMS were weighted after oven-drying for $48 \mathrm{~h}$. The detailed measurements have been reported in Yuan et al. (2016). The validity of the allometric models was verified by measuring another 13 branches of C6-C 8 and 14 branches of S6-S8.

\subsection{Calculations}

The raindrop attributes $(D, V$ and $A)$ were calculated on the basis of the best-fit equations developed from rainfall intensity and wind speed (Laws and Parsons, 1943; Gunn and Kinzer, 1949; Herwitz and Slye, 1995; Van Stan II et al., 2011; Carlyle-Moses and Schooling, 2015).

$$
\begin{aligned}
& D=2.23 \cdot(0.03937 \cdot I)^{0.102} \\
& V=(3.378 \cdot \ln (D))+4.213 \\
& \tan A=\mathrm{WS} / V
\end{aligned}
$$

where $D$ is the average raindrop diameter $(\mathrm{mm}), V$ is the terminal raindrop velocity $\left(\mathrm{m} \mathrm{s}^{-1}\right), A$ is the raindrop inclination angle from the vertical $\left(^{\circ}\right), I$ is the average intensity $\left(\mathrm{mm} \mathrm{h}^{-1}\right)$ and WS is the average wind speed $\left(\mathrm{m} \mathrm{s}^{-1}\right)$. 
Biomass and leaf traits were estimated by allometric models as an exponential function of BD (Siles et al., 2010a, b; Jonard et al., 2006):

$\mathrm{PT}_{\mathrm{e}}=a \cdot \mathrm{BD}^{b}$

where $a$ and $b$ are constants, and $\mathrm{PT}_{\mathrm{e}}$ refers to the estimated plant traits BML, BMS, LAB and LNB. The other plant traits could be calculated accordingly, including individual leaf area of branch $\left(\mathrm{ILAB}=100 \cdot \mathrm{LAB} / \mathrm{LNB}, \mathrm{mm}^{2}\right.$ ), and the percentage of stem biomass to that of branch $(\mathrm{PBMS}==\mathrm{BMS} /(\mathrm{BML}+\mathrm{BMS}) \cdot 100 \%, \%)$. Furthermore, the total stem-surface area of individual branch (SA) was computed representing by that of the main stem, which was idealized as the cone $(\mathrm{SA}=\pi \cdot \mathrm{BD} \cdot \mathrm{BL} / 20$, $\left.\mathrm{cm}^{2}\right)$. Therefore, specific surface area represented with $\mathrm{LAB}\left(\mathrm{SSAL}=\mathrm{LAB} /(\mathrm{BML}+\mathrm{BMS}), \mathrm{cm}^{2} \mathrm{~g}^{-1}\right)$ and in $\mathrm{SA}$ $\left(\mathrm{SSAS}=\mathrm{SA} /(\mathrm{BML}+\mathrm{BMS}), \mathrm{cm}^{2} \mathrm{~g}^{-1}\right)$ could be calculated. It was important to notice that this method underestimated the real stem-surface area by ignoring the collateral stems and assuming main stem as the standard corn, and therefore the SA and SSAS would not feed into the statistical analysis, but rather be applied to reflect a general correlation with $\mathrm{SF}_{\mathrm{b}}$ in this study.

In this study, stemflow yield was defined as the stemflow volume production of branch (hereafter "stemflow production", $\mathrm{SF}_{\mathrm{b}}, \mathrm{mL}$ ), the equivalent water depth on basis of shrub canopy area (hereafter "stemflow depth", $\mathrm{SF}_{\mathrm{d}}, \mathrm{mm}$ ) and the stemflow percentage of the incident precipitation amount (hereafter "stemflow percentage", SF \%, \%):

$\mathrm{SF}_{\mathrm{d}}=10 \cdot \sum_{i=1}^{n} \mathrm{SF}_{\mathrm{b}_{i}} / \mathrm{CA}$

$\mathrm{SF} \%=\left(\mathrm{SF}_{\mathrm{d}} / P\right) \cdot 100 \%$,

where $\mathrm{SF}_{\mathrm{b}_{i}}$ is the stemflow volume of branch $i(\mathrm{~mL}), \mathrm{CA}$ is the canopy area $\left(\mathrm{cm}^{2}\right), n$ is the number of branches and $P$ is the incident precipitation amount $(\mathrm{mm})$.

SFP $\left(\mathrm{mL} \mathrm{g}^{-1}\right)$ was expressed as the $\mathrm{SF}_{\mathrm{b}}(\mathrm{mL})$ of unit branch biomass $(\mathrm{g})$ and represented the stemflow efficiency of different-sized branches in association with a biomass allocation pattern:

$\mathrm{SFP}=\mathrm{SF}_{\mathrm{b}} /(\mathrm{BML}+\mathrm{BMS})$.

The FR was computed as the quotient of $\mathrm{SF}_{\mathrm{b}}$ and the product of $P$ and BBA (branch basal area; $\mathrm{cm}^{2}$ ) (Herwitz, 1986). The value of $(P \cdot \mathrm{BBA})$ equals to the precipitation amount that would have been caught by the rain gauge occupying the same basal area in a clearing. A FR with a value greater than 1 indicated a positive effect of the canopy on the stemflow yield (Carlyle-Moses and Price, 2006):

$\mathrm{FR}=10 \cdot \mathrm{SF}_{\mathrm{b}} /(P \cdot \mathrm{BBA})$

\subsection{Data analysis}

A Pearson correlation analysis was performed to test the relationship between $\mathrm{SF}_{\mathrm{b}}$ and each of the meteorological characteristics $\left(P, \mathrm{RD}, \mathrm{RI}, I, I_{5}, I_{10}, I_{30}, \mathrm{WS}, T, H, \mathrm{SR}, D\right.$, $V$ and $A$ ) and plant traits (BD, BL, BA, LAB, LNB, ILAB, BML, BMS and PBMS). Significantly correlated variables were further tested with a partial correlation analysis for their separate effects on $\mathrm{SF}_{\mathrm{b}}$. Then, the qualified variables were fed into a stepwise regression with forward selection to identify the most influential bio-/abiotic factors (CarlyleMoses and Schooling, 2015; Yuan et al., 2016). Similar to a principal component analysis and ridge regression, stepwise regression was commonly used because it got a limited effect of multicollinearity (Návar and Bryan, 1990; Honda et al., 2015; Carlyle-Moses and Schooling, 2015). Moreover, we excluded variables that had a variance inflation factor (VIF) greater than 10 to minimize the effects of multicollinearity (O'Brien, 2007), and kept the regression model having the least AIC (Akaike information criteria) values and largest $R^{2}$. The separate contribution of individual variables to stemflow yield and efficiency was computed by the method of variance partitioning. The same analysis methods were also applied to identify the most influential bio-/abiotic factors affecting SFP and FR. The level of significance was set at $95 \%$ confidence interval $(p=0.05)$. The SPSS 20.0 (IBM Corporation, Armonk, NY, USA), Origin 8.5 (OriginLab Corporation, Northampton, MA, USA) and Excel 2013 (Microsoft Corporation, Redmond, WA, USA) were used for data analysis.

\section{Results}

\subsection{Meteorological characteristics}

Stemflow was measured at 36 rainfall events in this study, 18 events $(209.8 \mathrm{~mm})$ in 2014 and 18 events $(205.3 \mathrm{~mm})$ in 2015 , which accounted for 32.7 and $46.2 \%$ of total rainfall events, and 73.1 and $74.9 \%$ of total precipitation amount during the experimental period of 2014 and 2015, respectively (Fig. 3). There were 4, 7, 10, 5, 4 and 6 rainfall events at precipitation categories of $\leq 2,2-5,5-10,10-15,15-20$, and $>20 \mathrm{~mm}$, respectively. The average rainfall intensity of incident rainfall events was $6.3 \pm 1.5 \mathrm{~mm} \mathrm{~h}^{-1}$, and the average value of $I_{5}, I_{10}$ and $I_{30}$ were $20.3 \pm 3.9,15.0 \pm 2.9$ and $9.2 \pm 1.6 \mathrm{~mm} \mathrm{~h}^{-1}$, respectively. RD and RI were averaged $5.5 \pm 1.1$ and $63.1 \pm 8.2 \mathrm{~h}$. The average $T, H, \mathrm{SR}, \mathrm{WS}$ and WD were $16.5 \pm 0.5^{\circ} \mathrm{C}, 85.9 \pm 2.2 \%, 48.5 \pm 11.2 \mathrm{kw} \mathrm{m}^{-2}$, $2.2 \pm 0.2 \mathrm{~m} \mathrm{~s}^{-1}$ and $167.1 \pm 13.9$, respectively. As to the raindrop attributes, $D, V$ and $A$ were averaged $1.8 \pm 0.4 \mathrm{~mm}$, $6.1 \pm 0.1 \mathrm{~m} \mathrm{~s}^{-1}$ and $19.6 \pm 1.2^{\circ}$, respectively. 


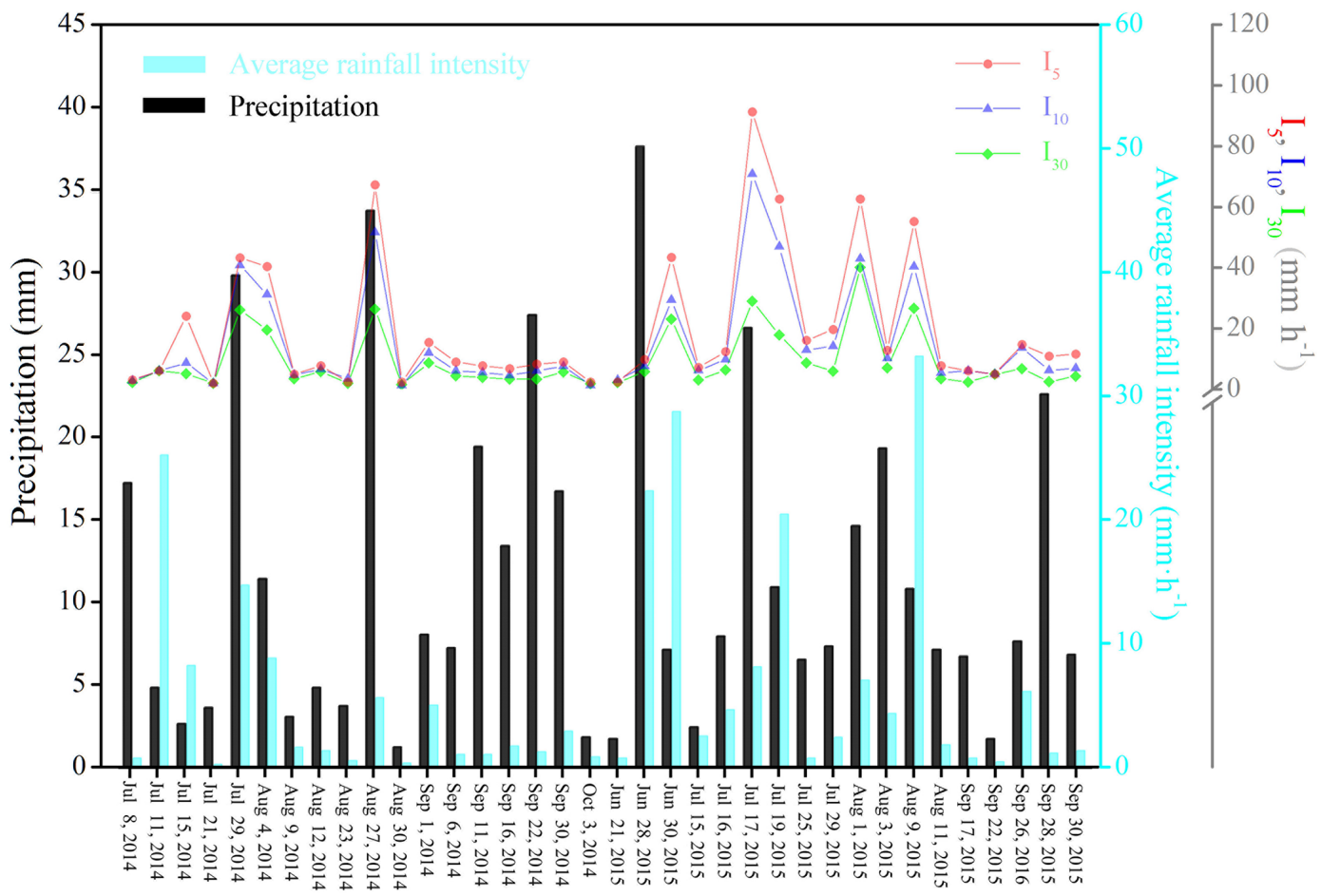

Figure 3. Meteorological characteristics of rainfall events for stemflow measurements during the 2014 and 2015 rainy seasons.
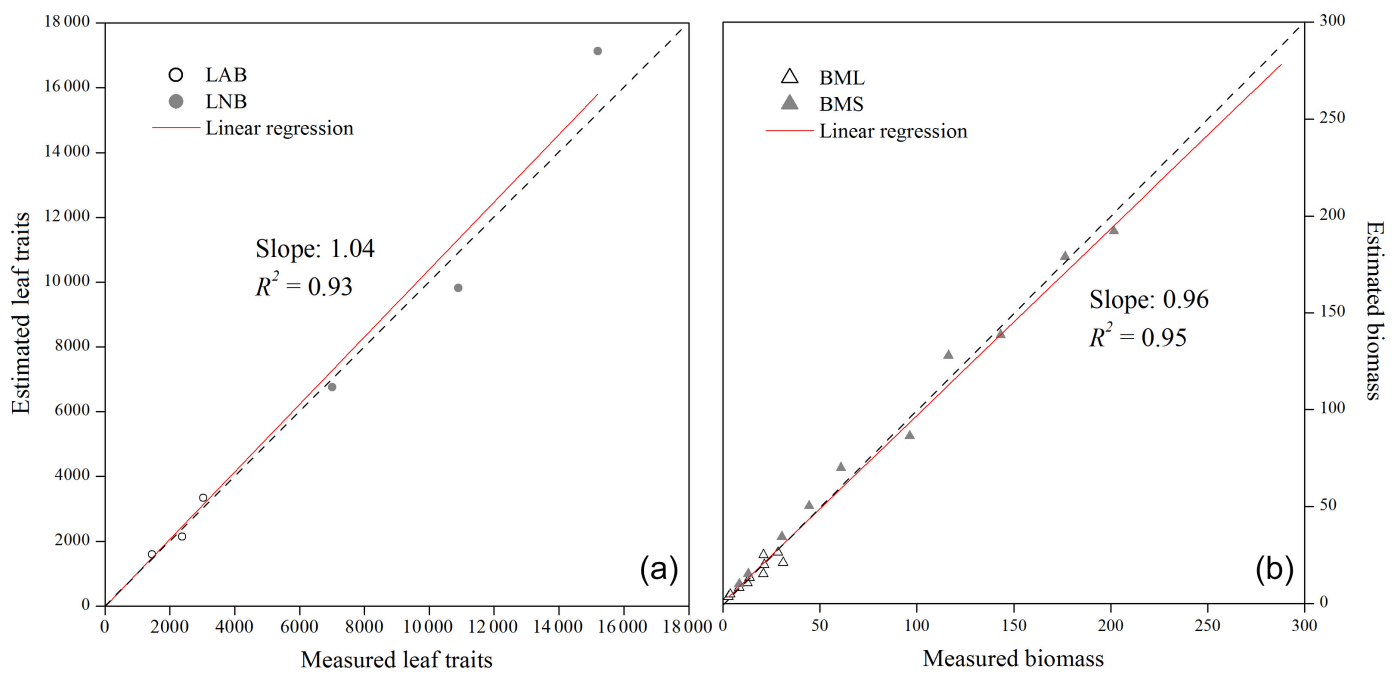

Figure 4. Verification of the allometric models for estimating the biomass and leaf traits of C. korshinskii. BML and BMS refer to the biomass of the leaves and stems, respectively, and LAB and LNB refer to the leaf area and the number of branches, respectively.

\subsection{Species-specific variation of plant traits}

Allometric models were developed to estimate the biomass and leaf traits of the branches of C. korshinskii and S. psammophila measured for stemflow. The estimation quality was verified by linear regression. As shown in Fig. 4, the regression of LAB, LNB, BML and BMS of $C$. korshinskii had an approximately $1: 1$ slope ( 0.99 for the biomass indicators and 1.04 for the leaf traits) and an $R^{2}$ value of $0.93-0.95$. According to Yuan et al. (2016), the regression of $S$. psammophila had a slope of 1.13 and an $R^{2}$ of 0.92 . Therefore, those allometric models were appropriate.

C. korshinskii had a similar average branch size and angle, but a shorter branch length than did $S$. psammophila, e.g., $12.5 \pm 4.2 \mathrm{~mm}$ vs. $13.7 \pm 4.4 \mathrm{~mm}, 60 \pm 18^{\circ}$ vs. $60 \pm 20^{\circ}$, and $161.5 \pm 35.0 \mathrm{~cm}$ vs. $267.3 \pm 49.7 \mathrm{~cm}$, respectively. $\mathrm{Re}-$ 
Table 1. Comparison of leaf traits, branch morphology and biomass indicators of C. korshinskii and S. psammophila.

\begin{tabular}{|c|c|c|c|c|c|c|c|c|c|c|c|}
\hline \multicolumn{2}{|c|}{ Plant traits } & \multicolumn{5}{|c|}{ C. korshinskii (categorized by BD, mm) } & \multicolumn{5}{|c|}{ S. psammophila(categorized by BD, mm) } \\
\hline & & $5-10$ & $10-15$ & $15-18$ & $>18$ & Avg. (BD) & $5-10$ & $10-15$ & $15-18$ & $>18$ & Avg. (BD) \\
\hline \multirow[t]{5}{*}{ Leaf traits } & $\operatorname{LAB}\left(\mathrm{cm}^{2}\right)$ & 1202.7 & 2394.5 & 3791.2 & 5195.2 & $2509.1 \pm 1355.3$ & 499.2 & 1317.7 & 2515.2 & 3533.6 & $1797.9 \pm 1118.0$ \\
\hline & LNB & 4787 & 11326 & 20071 & 29802 & $12479 \pm 8409$ & 392 & 1456 & 3478 & 5551 & $2404 \pm 1922$ \\
\hline & $\operatorname{ILAB}\left(\mathrm{mm}^{2}\right)$ & 25.4 & 21.3 & 18.9 & 17.5 & $21.9 \pm 3.0$ & 135.1 & 93.1 & 72.6 & 64.3 & $93.1 \pm 27.8$ \\
\hline & $\operatorname{SSAL}\left(\mathrm{cm}^{2} \mathrm{~g}^{-1}\right)$ & 22.8 & 17.3 & 14.3 & 12.6 & $18.2 \pm 0.5$ & 18.4 & 13.6 & 10.8 & 8.6 & $12.7 \pm 0.4$ \\
\hline & $\operatorname{SSAS}\left(\mathrm{cm}^{2} \mathrm{~g}^{-1}\right)$ & 3.4 & 2.3 & 1.9 & 1.6 & $2.5 \pm 0.1$ & 10.4 & 5.4 & 3.3 & 1.9 & $5.1 \pm 0.3$ \\
\hline \multirow{4}{*}{$\begin{array}{l}\text { Branch } \\
\text { morphology }\end{array}$} & $\mathrm{BD}(\mathrm{mm})$ & 8.17 & 12.49 & 16.61 & 20.16 & $12.48 \pm 4.16$ & 7.91 & 12.48 & 16.92 & 19.76 & $13.73 \pm 4.36$ \\
\hline & $\mathrm{BL}(\mathrm{cm})$ & 137.9 & 160.3 & 195.9 & 200.7 & $161.5 \pm 35.0$ & 212.5 & 260.2 & 290.4 & 320.1 & $267.3 \pm 49.7$ \\
\hline & $\mathrm{BA}\left({ }^{\circ}\right)$ & 63 & 56 & 63 & 64 & $60 \pm 18$ & 64 & 63 & 51 & 60 & $60 \pm 20$ \\
\hline & $\mathrm{SA}\left(\mathrm{cm}^{2}\right)$ & 176.8 & 314.1 & 508.6 & 630.7 & $326.1 \pm 20.6$ & 268.0 & 514.1 & 827.7 & 1312.3 & $711.0 \pm 38.9$ \\
\hline \multirow{3}{*}{$\begin{array}{l}\text { Biomass } \\
\text { indicators }\end{array}$} & BML (g) & 13.9 & 19.0 & 30.2 & 41.4 & $19.9 \pm 10.8$ & 5.4 & 18.0 & 40.0 & 61.3 & $27.9 \pm 20.7$ \\
\hline & BMS (g) & 62.9 & 121.4 & 236.4 & 375.8 & $141.1 \pm 110.8$ & 23.0 & 81.4 & 188.5 & 295.5 & $130.7 \pm 101.4$ \\
\hline & PBMS (\%) & 82.0 & 86.3 & 88.7 & 90.0 & $85.6 \pm 3.1$ & 80.8 & 81.8 & 82.5 & 82.8 & $81.9 \pm 0.8$ \\
\hline
\end{tabular}

Note: LAB and LNB are leaf area and number of branch, respectively. ILAB is individual leaf area of branch. SSAL and SSAS are the specific surface area representing with LAB and SA, respectively. BD, $\mathrm{BL}$ and BA are average branch basal diameter, length and angle, respectively. SA is the surface area of stems. BML and BMS are biomass of leaves and stems, respectively. PBMS is the percentage of stem biomass to that of branch. The average values mentioned above are expressed as the means $\pm \mathrm{SE}$.

garding branch biomass accumulation, $C$. korshinskii had a smaller BML (an average of $19.9 \pm 10.8 \mathrm{~g}$ ) and a larger BMS (an average $141.1 \pm 110.8 \mathrm{~g}$ ) than did $S$. psammophila (an average of $27.9 \pm 20.7$ and $130.7 \pm 101.4 \mathrm{~g}$, respectively). Both the BML and BMS increased with increasing branch size for these two shrub species. When expressed as a proportion, C. korshinskii had a larger PBMS than did S. psammophila in all the BD categories. The PBMS-specific difference increased with an increasing branch size, ranging from $1.2 \%$ for the $5-10 \mathrm{~mm}$ branches to $7.2 \%$ for the $>18 \mathrm{~mm}$ branches.

An increase in $\mathrm{LAB}$ and $\mathrm{LNB}$, and a decrease in ILAB, SSAL and SSAS were observed with increasing branch size for these two shrub species. But at each BD level, C. korshinskii had on average a larger LAB $\left(2509.1 \pm 1355.3 \mathrm{~cm}^{2}\right)$, LNB $(12479 \pm 8409)$ and SSAL $\left(18.2 \pm 0.5 \mathrm{~cm}^{2} \mathrm{~g}^{-1}\right)$, but a smaller ILAB $\left(21.9 \pm 3.0 \mathrm{~mm}^{2}\right)$ and SSAS $\left(2.5 \pm 0.1 \mathrm{~cm}^{2} \mathrm{~g}^{-1}\right)$ than did S. psammophila $\left(1797.9 \pm 1118.0 \mathrm{~g}, \quad 2404 \pm 1922, \quad 12.7 \pm 0.4 \mathrm{~cm}^{2} \mathrm{~g}^{-1}\right.$, $93.1 \pm 27.8 \mathrm{~mm}^{2}$ and $5.1 \pm 0.3 \mathrm{~cm}^{2} \mathrm{~g}^{-1}$, respectively) (Table 1). The inter-specific differences in the leaf traits decreased with increasing branch size. The largest difference occurred for the 5-10 mm branches, e.g., LNB and LAB were 12.2-fold and 2.4-fold larger for C. korshinskii, and ILAB was 5.3-fold larger for S. psammophila.

In the controlled field experiment, the defoliated sample branches of C. korshinskii and S. psammophila had similar branch morphology and BML with those of the foliated branches. The average BD, BL, BA and BML were $10.5 \pm 4.4 \mathrm{~mm}, 168.5 \pm 39.5 \mathrm{~cm}, 65 \pm 15^{\circ}$ and $22.2 \pm 11.6 \mathrm{~g}$ in $\mathrm{C} 5$, and $14.8 \pm 6.4 \mathrm{~mm}, 258.6 \pm 39.0 \mathrm{~cm}, 50 \pm 23^{\circ}$ and $27.3 \pm 22.1 \mathrm{~g}$ in $\mathrm{S} 5$, respectively.

\subsection{Stemflow yield of the foliated and defoliated C. korshinskii and S. psammophila}

In this study, stemflow yield was expressed as $\mathrm{SF}_{\mathrm{b}}$ on the branch scale and $\mathrm{SF}_{\mathrm{d}}$ and $\mathrm{SF} \%$ on the shrub scale. For the foliated shrubs, $\mathrm{SF}_{\mathrm{b}}$ was averaged 290.6 and $150.3 \mathrm{~mL}$ for individual branches of $C$. korshinskii and S. psammophila, respectively, per incident rainfall events during the 2014 and 2015 rainy seasons. The $\mathrm{SF}_{\mathrm{b}}$ was positively correlated with the branch size and precipitation for these two shrub species. As the branch size increased, $\mathrm{SF}_{\mathrm{b}}$ increased from the average of $119.0 \mathrm{~mL}$ for the $5-10 \mathrm{~mm}$ branches to $679.9 \mathrm{~mL}$ for the $>18 \mathrm{~mm}$ branches of $C$. korshinskii and from 43.0 to $281.8 \mathrm{~mL}$ for the corresponding BD categories of $S$. psammophila. However, with increasing precipitation, a larger intra-specific difference in $\mathrm{SF}_{\mathrm{b}}$ was observed, which increased from the average of $28.4 \mathrm{~mL}$ during rains $\leq 2 \mathrm{~mm}$ to $771.4 \mathrm{~mL}$ during rains $>20 \mathrm{~mm}$ for $C$. korshinskii and from 9.0 to $444.3 \mathrm{~mL}$ for the corresponding precipitation categories of $S$. psammophila. The $\mathrm{SF}_{\mathrm{b}}$ varied significantly for different rainfall characteristics and plant traits. The average $\mathrm{SF}_{\mathrm{b}}$ of $2375.9 \mathrm{~mL}$ occurred for the $>18 \mathrm{~mm}$ branches of $C$. korshinskii during rains $>20 \mathrm{~mm}$ in the 2014 and 2015 rainy seasons. However, the SF of $6.8 \mathrm{~mL}$ occurred for the $5-10 \mathrm{~mm}$ branches during rains $\leq 2 \mathrm{~mm}$. Comparatively, a maximum and minimum $\mathrm{SF}_{\mathrm{b}}$ of 2097.6 and $1.8 \mathrm{~mL}$ occurred for S. psammophila under similar bio-/abiotic conditions.

C. korshinskii produced a larger $\mathrm{SF}_{\mathrm{b}}$ than did S. psammophila for all $\mathrm{BD}$ and precipitation categories, and the interspecific differences in $\mathrm{SF}_{\mathrm{b}}$ also varied substantially with the rainfall characteristics and the plant traits. A maximum difference of 4.3-fold larger for the $\mathrm{SF}_{\mathrm{b}}$ of $C$. korshinskii was observed for the $>18 \mathrm{~mm}$ branches during rains $\leq 2 \mathrm{~mm}$ at the 2014 and 2015 rainy seasons. As the precipitation in- 
creased, the $\mathrm{SF}_{\mathrm{b}}$-specific difference decreased from 3.2-fold larger for $C$. korshinskii during rains $\leq 2 \mathrm{~mm}$ to 1.7 -fold larger during rains $>20 \mathrm{~mm}$. The largest $\mathrm{SF}_{\mathrm{b}}$-specific difference occurred for the $5-10 \mathrm{~mm}$ branches in almost all precipitation categories, but no clear trend of change was observed with increasing branch size (Table 2).

$\mathrm{SF}_{\mathrm{d}}$ and $\mathrm{SF} \%$ averaged $1.0 \mathrm{~mm}$ and $8.0 \%$ per incident rainfall events during the 2014 and 2015 rainy seasons for individual C. korshinskii shrubs, and $0.8 \mathrm{~mm}$ and $5.5 \%$ for individual S. psammophila shrubs, respectively. These parameters increased with increasing precipitation, ranging from $0.09 \mathrm{~mm}$ and $5.8 \%$ during rains $\leq 2$ to $2.6 \mathrm{~mm}$ and $8.9 \%$ during rains $>20 \mathrm{~mm}$ for $C$. korshinskii, and from less than $0.01 \mathrm{~mm}$ and $0.7 \%$ to $2.2 \mathrm{~mm}$ and $7.9 \%$ for the corresponding precipitation categories of $S$. psammophila, respectively. Additionally, the individual $C$. korshinskii shrubs had a larger stemflow yield than did S. psammophila in all precipitation categories. The differences in $\mathrm{SF}_{\mathrm{d}}$ and $\mathrm{SF} \%$ maximized as an 8.5- and 8.3-fold larger for C. korshinskii during rains $\leq 2 \mathrm{~mm}$ and decreased with increasing precipitation to 1.2 and 1.1-fold larger during rains $>20 \mathrm{~mm}$.

While comparing the intra-specific difference of $\mathrm{SF}_{\mathrm{b}}$ between different leaf states, $\mathrm{SF}_{\mathrm{b}}$ of the defoliated S. psammophila was 1.3-fold larger than the foliated S. psammophila on average, ranging from 1.1-, 1.0- and 1.4-fold larger for the 5-10, 10-15 and $>15 \mathrm{~mm}$ branches, respectively. A larger difference was noted during lighter rains (Table 3). On the contrary, $\mathrm{SF}_{\mathrm{b}}$ of the defoliated C. korshinskii was averaged 2.5-fold smaller than the foliated $C$. korshinskii at all rainfall events. Except for a 1.2-fold larger at the 5-10 mm branches, the 3.3-fold smaller $\mathrm{SF}_{\mathrm{b}}$ was measured at the 10$15 \mathrm{~mm}$ and $>15 \mathrm{~mm}$ branches of the defoliated C. korshinskii as opposed to the foliated C. korshinskii (Table 3). While comparing the $\mathrm{SF}_{\mathrm{b}}$-specific difference at the same leaf states, a smaller $\mathrm{SF}_{\mathrm{b}}$ of the foliated $S$. psammophila was noted than that of the foliated C. korshinskii. However, $\mathrm{SF}_{\mathrm{b}}$ of the defoliated S. psammophila was 2.0-fold larger than that of the defoliated $C$. korshinskii on average at nearly all BD categories except for the 5-10 $\mathrm{mm}$ branches (Table 3).

\subsection{Stemflow efficiency of C. korshinskii and S. psammophila}

With the combined results of SFP and FR, stemflow efficiency was assessed for C. korshinskii and S. psammophila. SFP averaged 1.95 and $1.19 \mathrm{~mL} \mathrm{~g}^{-1}$ for individual $C$. korshinskii and S. psammophila branches, respectively, per incident rainfall events during the 2014 and 2015 rainy seasons (Table 4). As precipitation increased, SFP increased from $0.19 \mathrm{~mL} \mathrm{~g}^{-1}$ during rains $\leq 2 \mathrm{~mm}$ to $5.08 \mathrm{~mL} \mathrm{~g}^{-1}$ during rains $>20 \mathrm{~mm}$ for $C$. korshinskii, and from 0.07 to $3.43 \mathrm{~mL} \mathrm{~g}^{-1}$ for the corresponding precipitation categories for S. psammophila. With an increase in branch size, SFP decreased from $2.19 \mathrm{~mL} \mathrm{~g}^{-1}$ for the $5-10 \mathrm{~mm}$ branches to $1.62 \mathrm{~mL} \mathrm{~g}^{-1}$ for the $>18 \mathrm{~mm}$ branches of $C$. korshinskii, and from 1.64 to $0.80 \mathrm{~mL} \mathrm{~g}^{-1}$ for the corresponding BD categories of $S$. psammophila. Maximum SFP values of 5.60 and $4.59 \mathrm{~mL} \mathrm{~g}^{-1}$ were recorded for C. korshinskii and S. psammophila, respectively. Additionally, C. korshinskii had larger SFP than did S. psammophila for all precipitation and BD categories. This inter-specific difference in SFP decreased with increasing precipitation from 2.7-fold larger for $C$. $k o$ rshinskii during rains $\leq 2 \mathrm{~mm}$ to 1.5 -fold larger during rains $>20 \mathrm{~mm}$, and it increased with increasing branch size: from 1.3-fold larger for C. korshinskii for the 5-10 mm branches to 2.0-fold larger for the $>18 \mathrm{~mm}$ branches.

FR averaged 173.3 and 69.3 for the individual branches of C. korshinskii and S. psammophila per rainfall events during the 2014 and 2015 rainy seasons, respectively (Table 5). As the precipitation increased, an increasing trend was observed, ranging from the average FR of 129.2 during rains $\leq 2 \mathrm{~mm}$ to 190.3 during rains $>20 \mathrm{~mm}$ for C. korshinskii and from the average FR of 36.7 to 96.1 during the corresponding precipitation categories for S. psammophila. FR increased with increasing BA from the average of 149.9 for the $\leq 30^{\circ}$ branches to 198.2 for the $>80^{\circ}$ branches of $\mathrm{C}$. korshinskii and from the average of 55.0 to 85.6 for the corresponding BA categories of $S$. psammophila. Maximum FR values of 276.0 and 115.7 were recorded for $C$. korshinskii and S. psammophila, respectively. Additionally, C. korshinskii had a larger FR than $S$. psammophila for all precipitation and BA categories. The inter-specific difference in FR decreased with increasing precipitation from 3.5 -fold larger for $C$. korshinskii during rains $\leq 2 \mathrm{~mm}$ to 2.0 -fold larger during rains $>20 \mathrm{~mm}$, and it decreased with an increase in the branch inclination angle: from 2.7-fold larger for C. korshinskii for the $\leq 30^{\circ}$ branches to 2.3 -fold larger for the $>80^{\circ}$ branches.

\subsection{Bio-/abiotic influential factors of stemflow yield and efficiency}

For both $C$. korshinskii and S. psammophila, BA was the only plant trait that had no significant correlation with $\mathrm{SF}_{\mathrm{b}}$ $(r<0.13, p>0.05)$ as indicated by the Pearson correlation analysis. The separate effects of the remaining plant traits were verified by the partial correlation analysis, but BL, ILAB and PBMS failed this test. The rest of plant traits, including $\mathrm{BD}, \mathrm{LAB}, \mathrm{LNB}, \mathrm{BML}$ and $\mathrm{BMS}$, were regressed with $\mathrm{SF}_{\mathrm{b}}$ using the forward selection method. Biomass was finally identified as the most important biotic indicator that affected stemflow, which behaved differently in C. korshinskii for BMS and in S. psammophila for BML. The same methods were applied to analyze the influence of meteorological characteristics on $\mathrm{SF}_{\mathrm{b}}$ of these two shrub species. Tested by the Pearson correlation and partial correlation analyses, $\mathrm{SF}_{\mathrm{b}}$ related significantly with $P, I_{10}, \mathrm{RD}$ and $H$ for C. korshinskii, and with $P, I_{5}, I_{10}, I_{30}$ for $S$. psammophila. The stepwise regression finally identified the precipitation amount as the most influential meteorological characteristics 
Table 2. Comparison of stemflow yield $\left(\mathrm{SF}_{\mathrm{b}}, \mathrm{SF}_{\mathrm{d}}\right.$ and $\left.\mathrm{SF} \%\right)$ between the foliated C. korshinskii and S. psammophila.

\begin{tabular}{|c|c|c|c|c|c|c|c|c|c|}
\hline \multirow{2}{*}{$\begin{array}{l}\text { Intra- and inter-specific } \\
\text { differences }\end{array}$} & \multirow{2}{*}{$\begin{array}{l}\text { Stemflow } \\
\text { indicators }\end{array}$} & \multirow{2}{*}{$\begin{array}{l}\text { BD } \\
\text { categories } \\
(\mathrm{mm})\end{array}$} & \multicolumn{6}{|c|}{ Precipitation categories $(\mathrm{mm})$} & \multirow{2}{*}{$\begin{array}{l}\text { Avg. } \\
(P)\end{array}$} \\
\hline & & & $\leq 2$ & $2-5$ & $5-10$ & $10-15$ & $15-20$ & $>20$ & \\
\hline \multirow{7}{*}{$\begin{array}{l}\text { Intra-specific differences in } \\
\text { C. korshinskii }(\mathrm{CK})\end{array}$} & & $5-10$ & 10.7 & 29.8 & 73.5 & 109.9 & 227.6 & 306.1 & 119.0 \\
\hline & & $10-15$ & 26.0 & 64.0 & 166.1 & 236.0 & 478.6 & 689.7 & 262.4 \\
\hline & $\mathrm{SF}_{\mathrm{b}}(\mathrm{mL})$ & $15-18$ & 44.3 & 103.3 & 279.9 & 416.6 & 826.0 & 1272.3 & 464.5 \\
\hline & & $>18$ & 69.5 & 145.4 & 424.4 & 631.4 & 1226.9 & 1811.7 & 679.9 \\
\hline & & Avg. (BD) & 28.4 & 67.3 & 180.6 & 264.6 & 529.2 & 771.4 & 290.6 \\
\hline & $\mathrm{SF}_{\mathrm{d}}(\mathrm{mm})$ & $\mathrm{n} / \mathrm{a}$ & 0.1 & 0.2 & 0.6 & 0.9 & 1.9 & 2.6 & 1.0 \\
\hline & $\mathrm{SF} \%(\%)$ & $\mathrm{n} / \mathrm{a}$ & 5.8 & 6.6 & 8.8 & 7.5 & 10.1 & 8.9 & 8.0 \\
\hline \multirow{7}{*}{$\begin{array}{l}\text { Intra-specific differences in } \\
\text { S. psammophila }(\mathrm{SP})\end{array}$} & & $5-10$ & 2.8 & 8.9 & 28.8 & 47.2 & 66.5 & 120.0 & 43.0 \\
\hline & & $10-15$ & 7.6 & 23.2 & 76.6 & 134.6 & 188.3 & 353.5 & 121.8 \\
\hline & $\mathrm{SF}_{\mathrm{b}}(\mathrm{mL})$ & $15-18$ & 12.0 & 35.9 & 121.6 & 223.4 & 319.4 & 592.6 & 201.5 \\
\hline & & $>18$ & 16.2 & 52.3 & 165.5 & 289.2 & 439.6 & 860.4 & 281.8 \\
\hline & & Avg. (BD) & 9.0 & 28.0 & 91.6 & 162.2 & 234.8 & 444.3 & 150.3 \\
\hline & $\mathrm{SF}_{\mathrm{d}}(\mathrm{mm})$ & $\mathrm{n} / \mathrm{a}$ & $<0.1$ & 0.1 & 0.5 & 0.9 & 1.3 & 2.2 & 0.8 \\
\hline & $\mathrm{SF} \%(\%)$ & $\mathrm{n} / \mathrm{a}$ & 0.7 & 3.0 & 6.1 & 6.8 & 7.2 & 7.9 & 5.5 \\
\hline \multirow{7}{*}{$\begin{array}{l}\text { Inter-specific differences } \\
\text { (the ratio of the stemflow yield } \\
\text { of CK to that of SP) }\end{array}$} & & $5-10$ & 3.8 & 3.3 & 2.6 & 2.3 & 3.4 & 2.6 & 2.8 \\
\hline & & $10-15$ & 3.4 & 2.8 & 2.2 & 1.8 & 2.5 & 2.0 & 2.2 \\
\hline & $\mathrm{SF}_{\mathrm{b}}$ & $15-18$ & 3.7 & 2.9 & 2.3 & 1.9 & 2.6 & 2.2 & 2.3 \\
\hline & & $>18$ & 4.3 & 2.8 & 2.6 & 2.2 & 2.8 & 2.1 & 2.4 \\
\hline & & Avg. (BD) & 3.2 & 2.4 & 2.0 & 1.6 & 2.3 & 1.7 & 1.9 \\
\hline & $\mathrm{SF}_{\mathrm{d}}$ & $\mathrm{n} / \mathrm{a}$ & 8.5 & 2.2 & 1.3 & 1.0 & 1.5 & 1.2 & 1.3 \\
\hline & SF \% & $\mathrm{n} / \mathrm{a}$ & 8.3 & 2.2 & 1.4 & 1.1 & 1.4 & 1.1 & 1.4 \\
\hline
\end{tabular}

Note: BD is the branch basal diameter; $P$ is the precipitation amount; CK and SP are the abbreviations of C. korshinskii and S. psammophila, respectively. n/a means not applicable.

for the two shrub species. Although $I_{10}$ was another influential factor for $C$. korshinskii, it only made a $15.6 \%$ contribution to the $\mathrm{SF}_{\mathrm{b}}$ on average.

$\mathrm{SF}_{\mathrm{b}}$ and $\mathrm{SF}_{\mathrm{d}}$ had a good linear relationships with the precipitation amount $\left(R^{2} \geq 0.93\right)$ for both shrub species (Fig. 5). The $>0.9$ and $>2.1 \mathrm{~mm}$ rains were required to start $\mathrm{SF}_{\mathrm{b}}$ for C. korshinskii and S. psammophila, respectively. This was close to the 0.8 and $2.0 \mathrm{~mm}$ precipitation threshold calculated with $\mathrm{SF}_{\mathrm{d}}$. Moreover, the precipitation threshold increased with increasing branch size. The precipitation threshold values were $0.7,0.7,1.4$ and $0.8 \mathrm{~mm}$ for the $5-10,10-15$, $15-18$ and $>18 \mathrm{~mm}$ branches of $C$. korshinskii, and 1.1, 1.6, 2.0 and $2.4 \mathrm{~mm}$ for the branches of $S$. psammophila, respectively.

$\mathrm{SF} \%$ of the two shrub species were inversely proportional to the precipitation amount. As the precipitation increased, it gradually approached asymptotic values of 9.1 and $7.7 \%$ for C. korshinskii and S. psammophila, respectively. As shown in Fig. 5, fast growth was evident during rains $\leq 10 \mathrm{~mm}$, but SF \% slightly increased afterwards for both shrub species.

Precipitation amount was the most important factor affecting SFP and FR for C. korshinskii and S. psammophila, but the most important biotic factor was different. BA was the most influential plant trait that affected FR of these two shrub species at all precipitation levels. ILAB was the most important plant trait affecting SFP during rains $\leq 10 \mathrm{~mm}$ of these species. However, during heavier rains $>15 \mathrm{~mm}$, BD and PBMS were the most significant biotic factors for $C . \mathrm{ko}$ rshinskii and S. psammophila, respectively. For these two shrubs species, it was leaf trait (ILAB) and branch traits (biomass allocation pattern and branch size) that played bigger roles on SFP during lighter rains $\leq 10 \mathrm{~mm}$ and heavier rains $>15 \mathrm{~mm}$, respectively. Therefore, it seemed that the rainfall interception process of leaves controlled SFP during the lighter rains, which functioned as the water resource to produce stemflow. Nevertheless, while water supply was adequate during heavier rains, the stemflow delivering process of branches might be the bottleneck.

\section{Discussion}

\subsection{Differences of stemflow yield and efficiency between two shrub species}

C. korshinskii produced stemflow in a larger quantity compared with $S$. psammophila in all precipitation categories, particularly at the $5-10 \mathrm{~mm}$ young shoots during light rains $\leq 2 \mathrm{~mm}$ (Table 2). Although the greatest stemflow yield was observed during rains $>20 \mathrm{~mm}$ for the two shrub species, 


\section{C. korshinskii}
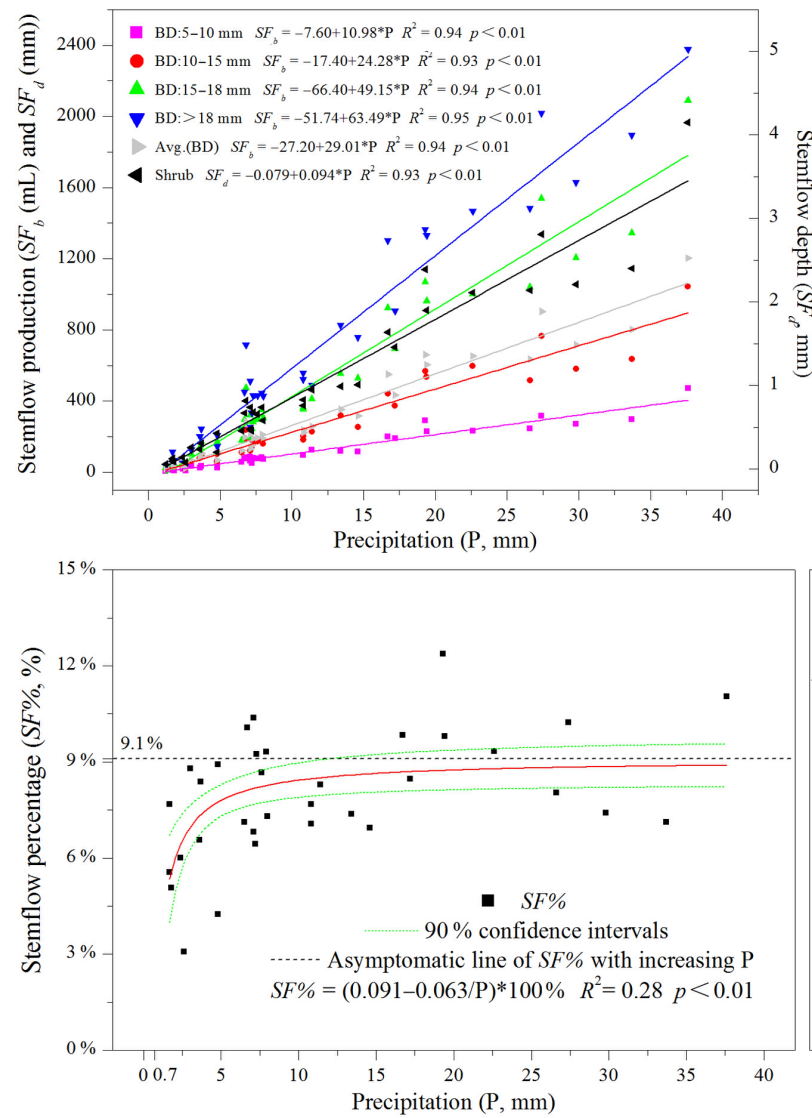

S. psammophila
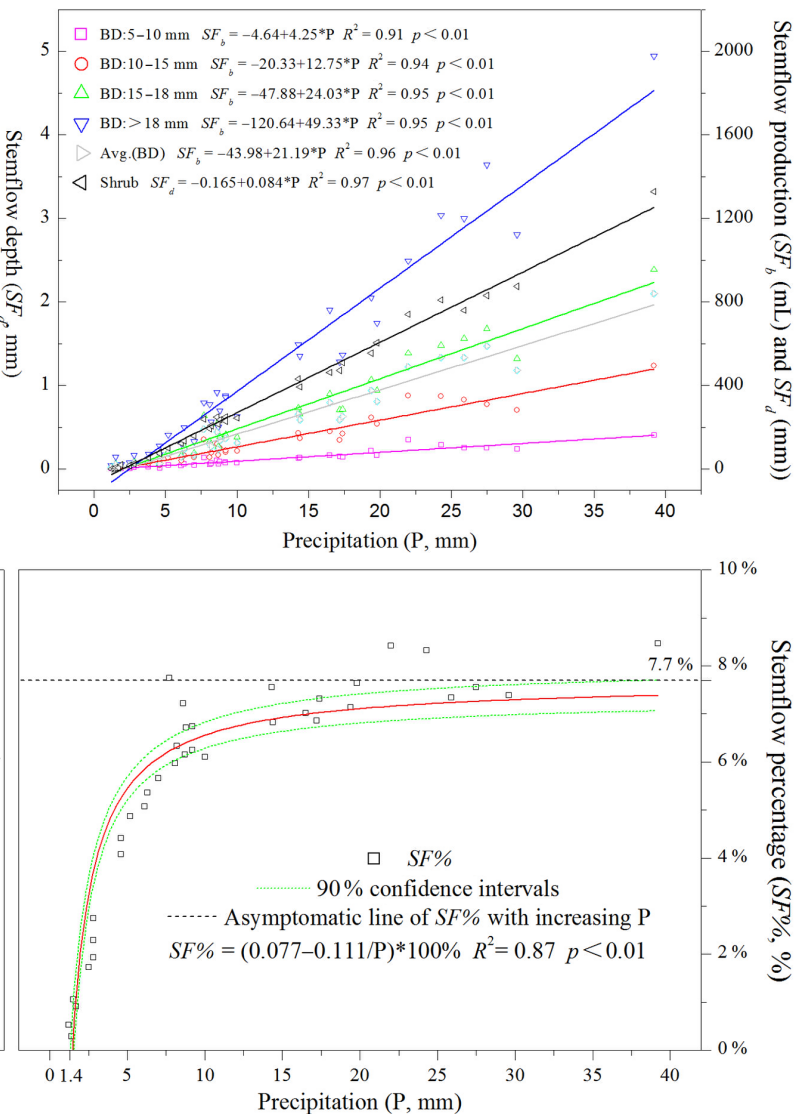

Figure 5. Relationships of branch stemflow volume $\left(\mathrm{SF}_{\mathrm{b}}\right)$, shrub stemflow depth $\left(\mathrm{SF}_{\mathrm{d}}\right)$ and stemflow percentage $(\mathrm{SF} \%)$ with precipitation amount $(P)$ for C. korshinskii and S. psammophila.

the inter-specific differences of $\mathrm{SF}_{\mathrm{b}}, \mathrm{SF}_{\mathrm{d}}$ and $\mathrm{SF} \%$ were the highest at 3.2-, 8.5- and 8.3-fold larger for C. korshinskii during rains $\leq 2 \mathrm{~mm}$, respectively. Additionally, C. korshinskii had a 2.8 -fold larger $\mathrm{SF}_{\mathrm{b}}$ than did S. psammophila for the $5-10 \mathrm{~mm}$ branches.

The average FR of C. korshinskii and S. psammophila were 173.3 and 69.3 per individual rainfall during the 2014 and 2015 rainy season in this study, which agreed well with 156.1 (Jian et al., 2014) and 153.5 (Li et al., 2008) for C. korshinskii at the western Loess Plateau of China, and 69.4 (Yang et al., 2008) for S. psammophila at the Mu Us sandland of China. These two shrub species had a larger FR than those of many other endemic xerophytic shrubs at waterstressed ecosystems, e.g., Tamarix ramosissima (24.8) (Li et al., 2008), Artemisia sphaerocephala (41.5) (Yang et al., 2008), Reaumuria soongorica (53.2) (Li et al., 2008), Hippophae rhamnoides (62.2) (Jian et al., 2014). Therefore, both C. korshinskii and S. psammophila employed precipitation in an efficient manner to produce stemflow, and C. korshinskii produced stemflow even more efficiently for all precipitation categories particularly during rains $\leq 2 \mathrm{~mm}$ (Table 5). The higher stemflow efficiency of $C$. korshinskii was also sup- ported by SFP in all the precipitation and BD categories $(\mathrm{Ta}-$ ble 4).

In conclusion, compared with S. psammophila, C. korshinskii produced stemflow at a greater amount and in a more efficient manner. Moreover, the $\mathrm{SF}_{\mathrm{b}}$-specific difference was the largest during lighter rains. Dryland shrubs generally experienced several wetting-drying cycles (Cui and Caldwell, 1997) when rains were sporadic. As an important source of rhizosphere soil moisture at dryland ecosystems (Dunkerley, 2000; Yang, 2010; Návar, 2011; Li et al., 2013), a considerable amount of stemflow could be produced by various species and infiltrated into deep soil during heavier rains. However, during lighter rains, the larger amount stemflow produced in more efficient manner might benefit xerophytic shrubs, as more soil moisture could be recharged especially at the root zone. Therefore, in addition to quantify the soil moisture recharge, a thorough study was required to depict the stemflow infiltration process, particularly at the waterstressed environment. 


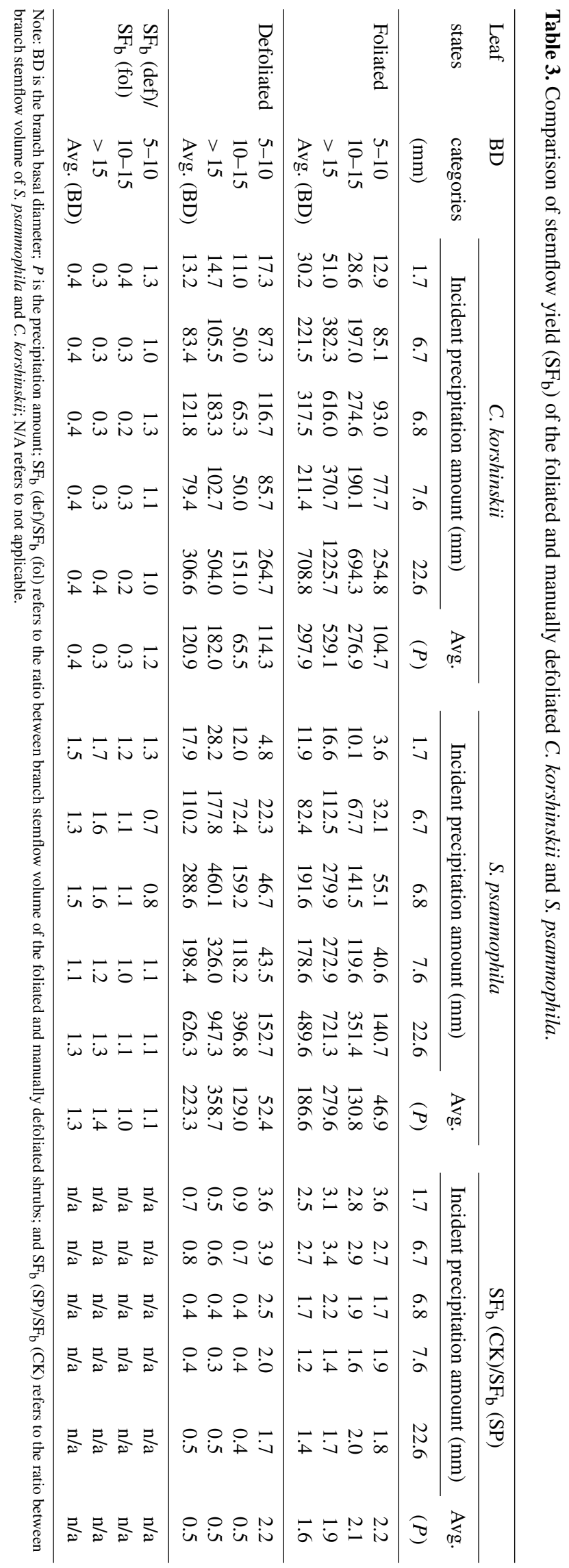

\subsection{Effects of precipitation threshold to produce stemflow}

Precipitation below the threshold wet the canopy and finally evaporated, and therefore it theoretically did not generate stemflow. The precipitation threshold varied with species and ecozones, for instance, $2.5 \mathrm{~mm}$ for the xerophytic Ashe juniper communities in central Texas, USA (Owens et al., 2006) or $5 \mathrm{~mm}$ for xerophytic shrubs (S. psammophila, Hedysarum scoparium, A. sphaerocephala and Artemisia ordosica) at the Mu Us sandland of China (Yang, 2010). Generally, for many xerophytic shrub species, it generally ranges in 0.4-2.2 mm (Belmonte Serrato and Romero Diaz, 1998; Li et al., 2008; Wang et al., 2013; Zhang et al., 2015). In this study, at least the 0.9 and $2.1 \mathrm{~mm}$ rainfalls were necessary to initiate stemflow in C. korshinskii and S. psammophila. That fell in the threshold range of $0.4-1.4 \mathrm{~mm}$ for $C$. korshinskii (Li et al., 2009; Wang et al., 2013), and agreed well with $2.2 \mathrm{~mm}$ for S. psammophila in the Mu Us sandland (Li et al., 2009).

Scant rainfall prevailed in arid and semiarid regions. The light rains took lead in events amount but ranked near the bottom in total precipitation amount among different precipitation categories (Owens et al., 2006; Yang, 2010; Jian et al., 2014). In this study, the rains $\leq 2 \mathrm{~mm}$ accounted for $45.7 \%$ of all the rainfall events and $7.2 \%$ of the precipitation amount during the 2014 and 2015 rainy seasons. C. korshinskii produced stemflow at more rainfall events (71 events) than those of $S$. psammophila (51 events) during the experimental period, which could be partly explained by their different precipitation threshold. Because of the $2.1 \mathrm{~mm}$ threshold, $S$. psammophila produced the limited amount of stemflow during 20 rainfall events of 1-2 mm, which took $21.3 \%$ of all rainfall events during the rainy season. Comparatively, stemflow yield during rains of $1-2 \mathrm{~mm}$ was an extra benefit for $C$. korshinskii, for a smaller precipitation threshold of $0.9 \mathrm{~mm}$ on average. Despite of a small amount of stemflow during light rains, the soil moisture replenishment and the resulting ecological responses were not negligible for dryland shrubs and the peripheral arid environment (Li et al., 2009). A $2 \mathrm{~mm}$ summer rain might stimulate the activity of soil microbes, resulting in an increase of soil nitrate in the semiarid Great Basin in western USA (Cui and Caldwell, 1997), and a brief decomposition pulse (Austin et al., 2004). The summer rains $\geq 3 \mathrm{~mm}$ were usually necessary to elevate rates of carbon fixation in some higher plants in southern Utah, USA (Schwinning et al., 2003), or for biological crusts to have a net carbon gain at eastern Utah, USA (Belnap et al., 2004). That benefited the formation and maintenance of the "fertile islands" (Whitford et al., 1997), "resource islands" (Reynolds et al., 1999) or "hydrologic islands" (Rango et al., 2006).

Therefore, a smaller precipitation threshold might entitle C. korshinskii with more available water at the root zone, because stemflow functioned as an important source of 
Table 4. Comparison of stemflow productivity (SFP) between the foliated C. korshinskii and S. psammophila.

\begin{tabular}{|c|c|c|c|c|c|c|c|c|}
\hline \multirow{2}{*}{$\begin{array}{l}\text { Intra- and inter-specific } \\
\text { differences }\end{array}$} & \multirow{2}{*}{$\begin{array}{l}\text { BD } \\
\text { categories } \\
(\mathrm{mm})\end{array}$} & \multicolumn{6}{|c|}{ Precipitation categories (mm) } & \multirow{2}{*}{$\begin{array}{r}\text { Avg. } \\
(P)\end{array}$} \\
\hline & & $\leq 2$ & $2-5$ & $5-10$ & $10-15$ & $15-20$ & $>20$ & \\
\hline \multirow{5}{*}{$\begin{array}{l}\text { Intra-specific differences in } \\
\text { C. korshinskii }(\mathrm{CK}) \\
\left(\mathrm{mL} \mathrm{g}^{-1}\right)\end{array}$} & $5-10$ & 0.20 & 0.56 & 1.37 & 2.04 & 4.18 & 5.60 & 2.19 \\
\hline & $10-15$ & 0.19 & 0.47 & 1.20 & 1.72 & 3.47 & 4.96 & 1.90 \\
\hline & $15-18$ & 0.17 & 0.38 & 1.05 & 1.55 & 3.08 & 4.74 & 1.73 \\
\hline & $>18$ & 0.15 & 0.35 & 1.00 & 1.46 & 2.95 & 4.35 & 1.62 \\
\hline & Avg. (BD) & 0.19 & 0.47 & 1.21 & 1.78 & 3.60 & 5.08 & 1.95 \\
\hline \multirow{5}{*}{$\begin{array}{l}\text { Intra-specific differences in } \\
\text { S. psammophila }(\mathrm{SP}) \\
\left(\mathrm{mL} \mathrm{g}^{-1}\right)\end{array}$} & $5-10$ & 0.11 & 0.34 & 1.10 & 1.83 & 2.51 & 4.59 & 1.64 \\
\hline & $10-15$ & 0.08 & 0.25 & 0.82 & 1.43 & 1.98 & 3.72 & 1.29 \\
\hline & $15-18$ & 0.05 & 0.16 & 0.53 & 0.97 & 1.40 & 2.61 & 0.88 \\
\hline & $>18$ & 0.05 & 0.15 & 0.47 & 0.82 & 1.25 & 2.44 & 0.80 \\
\hline & Avg. (BD) & 0.07 & 0.23 & 0.76 & 1.31 & 1.84 & 3.43 & 1.19 \\
\hline \multirow{5}{*}{$\begin{array}{l}\text { Inter-specific differences } \\
\text { (the ratio of the SFP values } \\
\text { of CK to that of SP) }\end{array}$} & $5-10$ & 1.8 & 1.7 & 1.3 & 1.1 & 1.7 & 1.2 & 1.3 \\
\hline & $10-15$ & 2.4 & 1.9 & 1.5 & 1.2 & 1.8 & 1.3 & 1.5 \\
\hline & $15-18$ & 2.8 & 2.4 & 2.0 & 1.6 & 2.2 & 1.8 & 2.0 \\
\hline & $>18$ & 3.0 & 2.3 & 2.1 & 1.8 & 2.4 & 1.8 & 2.0 \\
\hline & Avg. (BD) & 2.7 & 2.0 & 1.6 & 1.4 & 2.0 & 1.5 & 1.6 \\
\hline
\end{tabular}

Note: BD is the branch basal diameter; $P$ is the precipitation amount; $\mathrm{CK}$ and SP are the abbreviations of $C$. korshinskii and S. psammophila, respectively.

Table 5. Comparison of the funnelling ratio (FR) for the foliated C. korshinskii and S. psammophila.

\begin{tabular}{llrrrrrrr}
\hline \multirow{2}{*}{$\begin{array}{l}\text { Intra- and inter-specific } \\
\text { differences }\end{array}$} & BA & \multicolumn{3}{c}{ Precipitation categories (mm) } & Avg. \\
\cline { 2 - 7 } & $\begin{array}{l}\text { categories } \\
\left({ }^{\circ}\right)\end{array}$ & $\leq 2$ & $2-5$ & $5-10$ & $10-15$ & $15-20$ & $>20$ & $(P)$ \\
\hline Intra-specific differences in & $\leq 30$ & 100.2 & 127.7 & 168.1 & 125.3 & 193.1 & 170.3 & 149.9 \\
C. korshinskii (CK) & $30-60$ & 125.9 & 133.8 & 178.5 & 157.8 & 205.2 & 182.1 & 164.7 \\
& $60-80$ & 135.5 & 148.9 & 192.5 & 165.8 & 217.0 & 188.6 & 176.1 \\
& $>80$ & 133.2 & 167.4 & 205.5 & 182.6 & 276.0 & 226.1 & 198.2 \\
& Avg. (BA) & 129.2 & 144.8 & 187.7 & 162.3 & 219.6 & 190.3 & 173.3 \\
\hline Intra-specific differences in & $\leq 30$ & 32.6 & 37.3 & 52.0 & 59.0 & 65.8 & 85.2 & 55.0 \\
S. psammophila (SP) & $30-60$ & 34.5 & 43.4 & 65.7 & 70.6 & 77.7 & 92.3 & 64.8 \\
& $60-80$ & 37.8 & 47.9 & 78.0 & 78.4 & 82.3 & 97.7 & 72.4 \\
& $>80$ & 44.9 & 55.0 & 93.5 & 94.7 & 94.1 & 115.7 & 85.6 \\
& Avg. (BA) & 36.7 & 46.0 & 72.6 & 75.3 & 80.5 & 96.1 & 69.3 \\
\hline Inter-specific differences & $\leq 30$ & 3.1 & 3.4 & 3.2 & 2.1 & 2.9 & 2.0 & 2.7 \\
(the ratio of the FR values & $30-60$ & 3.7 & 3.1 & 2.7 & 2.2 & 2.6 & 2.0 & 2.5 \\
of CK to that of SP) & $60-80$ & 3.6 & 3.1 & 2.5 & 2.1 & 2.6 & 1.9 & 2.4 \\
& $>80$ & 3.0 & 3.0 & 2.2 & 1.9 & 2.9 & 2.0 & 2.3 \\
& Avg. (BA) & 3.5 & 3.2 & 2.6 & 2.2 & 2.7 & 2.0 & 2.5 \\
\hline
\end{tabular}

Note: BA is the branch inclined angle; $P$ is the precipitation amount; CK and SP are the abbreviations of $C$. korshinskii and S. psammophila, respectively.

available moisture in dryland ecosystems (Dunkerley, 2000; Yang, 2010; Návar, 2011; Li et al., 2013). That agreed with the findings of Dong and Zhang (2001) that S. psammophila belonged to the water-spending paradigm from the aspect of leaf water relations and anatomic features, and the finding of Ai et al. (2015) that $C$. korshinskii belonged to the water- saving paradigm and had larger drought tolerance ability than S. psammophila from the aspect of root anatomical structure and hydraulic traits. 


\subsection{Effects of leaf traits on stemflow yield}

Leaf traits had been recently reported for a significant influence on stemflow (Carlyle-Moses, 2004; Garcia-Estringana et al., 2010). The factors, such as a relatively large LNB (Levia et al., 2015; Li et al., 2016), a large LAB (Li et al., 2015), a high LAI (Liang et al., 2009), a big BML (Yuan et al., 2016), a scale-like leaf arrangement (Owens et al., 2006), a small ILAB (Sellin et al., 2012), a concave leaf shape (Xu et al., 2005), a densely veined leaf structure (Xu et al., 2005), an upward leaf orientation (Crockford and Richardson, 2000), leaf pubescence (Garcia-Estringana et al., 2010) and the leaf epidermis microrelief (e.g., the non-hydrophobic leaf surface and the grooves within it) (Roth-Nebelsick et al., 2012), together resulted in retaining a large amount of precipitation in the canopy, supplying water for stemflow yield and providing a beneficial morphology that enables the leaves to function as a highly efficient natural water collecting and channeling system.

According to the documentation at Flora of China (Chao and Gong, 1999; Liu et al., 2010) and the field observations in this study, $C$. korshinskii had more beneficial leaf morphology for stemflow yield than did S. psammophila, owing to a lanceolate and concave leaf shape, a pinnate compound leaf arrangement and a densely sericeous pressed pubescence (Fig. 6). Additionally, experimental measurements indicated that $C$. korshinskii had a larger MTA, LAB, LNB and LAI (an average of $54.4^{\circ}, 2509.1 \mathrm{~cm}^{2}, 12479$ and 2.4 , respectively) and a smaller ILAB (an average of $21.9 \mathrm{~mm}^{2}$ ) than did S. psammophila (an average of $48.5^{\circ}, 1797.9 \mathrm{~cm}^{2}, 2404$, 1.7 and $87.5 \mathrm{~mm}^{2}$, respectively). The concave leaf shape, upward leaf orientation (MTA) and densely veined leaf structure (ILAB) (Xu et al., 2005) provided stronger leaf structural support in $C$. korshinskii for the interception and transportation of precipitation, particularly during highly intense rains. Therefore, in addition to the leaf morphology, C. korshinskii was also equipped with more beneficial leaf structural features for stemflow yield.

A controlled field experiment was conducted for the foliated and manually defoliated C. korshinskii and S. psammophila simultaneously for the 2015 rainy season. Nevertheless, contradictory results were reached in this study. $\mathrm{SF}_{\mathrm{b}}$ of the foliated $C$. korshinskii was 2.5-fold larger than the defoliated $C$. korshinskii on average (Table 3), which seemed to demonstrate an overall positive effect of leaves affecting stemflow yield. However, it contradicted with the average 1.3-fold larger $\mathrm{SF}_{\mathrm{b}}$ of the defoliated S. psammophila than the foliated S. psammophila. Despite of the identical stand conditions, meteorological characteristics and plant traits, except for the leaf states, the changing interception area for raindrops, were not taken into account. It could be roughly represented by leaf area and stem-surface area at the foliated and defoliated state, respectively, which was generally ignored at many previous studies (Dolman, 1987; Masukata et al., 1990; Neal et al., 1993; Martinez-Meza and Whitford,

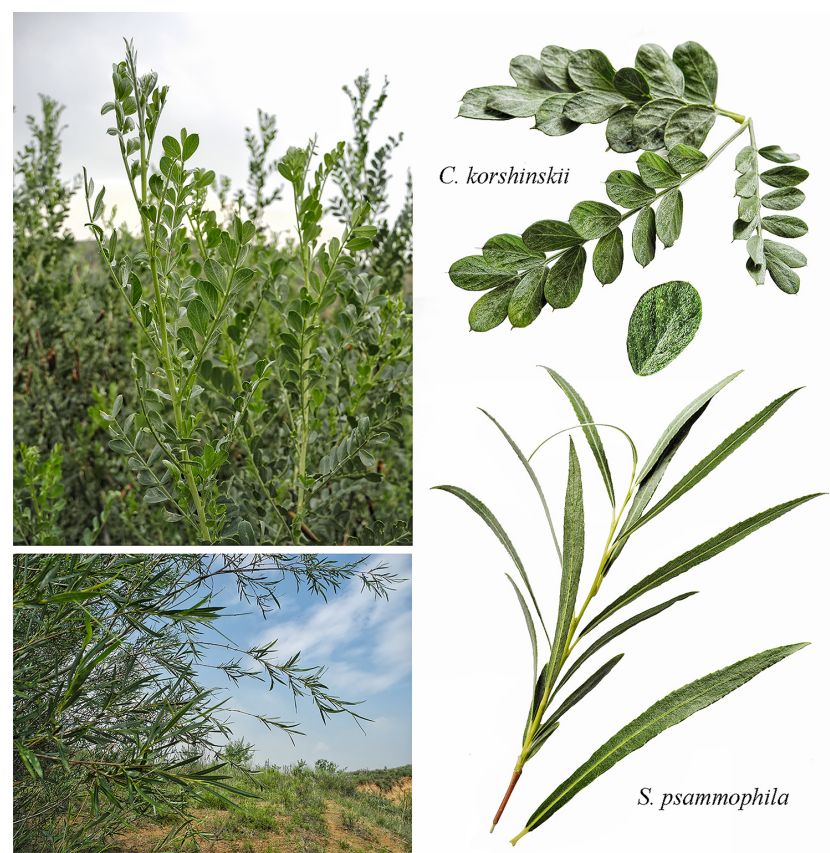

Figure 6. Comparison of leaf morphologies of C. korshinskii and S. psammophila.

1996; Deguchi et al., 2006; Liang et al., 2009; Mużyło et al., 2012). The changing interception area at different leaf states might explain the seemingly contradictory results. For comparing the inter-specific $\mathrm{SF}_{\mathrm{b}}$, the normalized area indexes of SSAL and SSAS was analyzed in this study. At the foliated state, a 1.4-fold larger SSAL of the C. korshinskii was corresponded to a 1.6-fold larger $\mathrm{SF}_{\mathrm{b}}$ than that of $S$. psammophila. But at the defoliated state, a 2.0-fold larger SSAS of S. psammophila corresponded to a 1.8-fold larger $\mathrm{SF}_{\mathrm{b}}$ than that of C. korshinskii (Tables 1 and 3). Indeed, it greatly underestimated the real stem-surface area of individual branches by ignoring the collateral stems and computing SA with the surface area of the main stem, which was assumed as a standard cone, in addition to a not big enough sample size of branches and rainfall events measured in this controlled field experiment. However, the positive relations of $\mathrm{SF}_{\mathrm{b}}$ with SSAL and SSAS at different leaf states might shed light on the longstanding discussion about leaf's effects on stemflow, which suggested some relevant plant traits that might need to be considered for better understanding the influential mechanism of stemflow yield. Although an identical meteorological features, stand conditions and similar plant traits were guaranteed, the experiment by comparing stemflow yield between the foliated and defoliated periods might provide no feasible evidence for leaf's effects (positive, negative or neglectable) affecting stemflow yield, if the newly exposed branch surface at the defoliated period and the resulting rainfall intercepting effect were not considered. 


\section{Conclusions}

Compared with S. psammophila, C. korshinskii produced a larger amount of stemflow more efficiently during different sized rains. An average 1.9-, 1.3-, 1.4-, 1.6- and 2.5fold larger in C. korshinskii was observed for the branch stemflow volume $\left(\mathrm{SF}_{\mathrm{b}}\right)$, the shrub stemflow depth $\left(\mathrm{SF}_{\mathrm{d}}\right)$, the shrub stemflow percentage (SF \%), the stemflow productivity (SFP) and the stemflow FR, respectively. The interspecific differences in stemflow yield $\left(\mathrm{SF}_{\mathrm{b}}, \mathrm{SF}_{\mathrm{d}}\right.$ and $\left.\mathrm{SF} \%\right)$ and the production efficiency (SFP and FR) were maximized for the $5-10 \mathrm{~mm}$ branches and during rains $\leq 2 \mathrm{~mm}$. The smaller threshold precipitation $(0.9 \mathrm{~mm}$ for $C$. korshinskii vs. $2.1 \mathrm{~mm}$ for $S$. psammophila), and the beneficial leaf traits might be partly responsible for the superior stemflow yield and efficiency in $C$. korshinskii.

Precipitation amount had the largest influence on both stemflow yield and efficiency for the two shrub species. BA was the most influential plant trait on FR. For $\mathrm{SF}_{\mathrm{b}}$, stem biomass and leaf biomass were the most influential plant traits in C. korshinskii and S. psammophila, respectively. But for SFP, leaf traits (the individual leaf area) and branch traits (branch size and biomass allocation pattern) had a larger influence in these two shrub species during lighter rains $\leq 10 \mathrm{~mm}$ and heavier rains $>15 \mathrm{~mm}$, respectively.

By comparing $\mathrm{SF}_{\mathrm{b}}$ between the foliated and manually defoliated shrubs simultaneously at the 2015 rainy season, a contradiction was noted: the larger stemflow yield of C. korshinskii at the foliated state, but the larger stemflow yield of S. psammophila at the defoliated state. That corresponded to the inter-specific difference of the specific surface area representing by leaves (SSAL) and stems (SSAS) at different leaf states, respectively. It shed light on the feasibility of experiments by comparing stemflow yield between the foliated and defoliated periods, which might provide no convincing evidence for leaf's effects (positive, negative or neglectable) affecting stemflow yield, if the newly exposed branch surface at the defoliated period and the resulting rainfall intercepting effects were not considered.

Data availability. All the data used in this study are available upon request.

Competing interests. The authors declare that they have no conflict of interest.

Acknowledgements. This research was funded in part by the National Natural Science Foundation of China (no. 41390462), the National Key Research and Development Program (no. 2016YFC0501602) and the Youth Innovation Promotion Association CAS (no. 2016040). We are grateful to Mengyu Wang, Dongyang Zhao, Meixia Mi and Hongmin Hao for field assistant, and Bingxia Liu for statistical analysis. Special thanks were given to the Shenmu Erosion and Environment Research Station for experiment support to this research. We thank the editor, David Dunkerley and another anonymous reviewer for their constructive comments, which greatly improve the quality of this manuscript.

Edited by: L. Wang

Reviewed by: D. Dunkerley and one anonymous referee

\section{References}

Ai, S. S., Li, Y. Y., Chen, J. C., and Chen, W. Y.: Root anatomical structure and hydraulic traits of three typical shrubs on the sandy lands of northern Shaanxi Province, China, Chinese J. Appl. Ecol., 26, 3277-3284, 2015.

Allaby, M.: A Dictionary of Ecology, 4th Edn., Oxford University Press, Oxford, 2010.

Andersson, T.: Influence of stemflow and throughfall from common oak (Quercus robur) on soil chemistry and vegetation patterns, Can. J. Forest Res., 21, 917-924, 1991.

André, F., Jonard, M., and Ponette, Q.: Influence of species and rain event characteristics on stemflow volume in a temperate mixed oak-beech stand, Hydrol. Process., 22, 4455-4466, 2008.

Austin, A. T., Yahdjian, L., Stark, J. M., Belnap, J., Porporato, A., Norton, U., Ravetta, D. A. and Schaeffer, S. M.: Water pulses and biogeochemical cycles in arid and semiarid ecosystems, Oecologia, 141, 221-235, 2004.

Belmonte Serrato, F. and Romero Diaz, A.: A simple technique for measuring rainfall interception by small shrub: "interception flow collection box”, Hydrol. Process., 12, 471-481, 1998.

Belnap, J., Philips, S. L., and Miller, M. E.: Response of desert biological soil crusts to alterations in precipitation frequency, Oecologia, 141, 306-316, 2004.

Carlyle-Moses, D. E.: Throughfall, stemflow, and canopy interception loss fluxes in a semi-arid Sierra Madre Oriental matorral community, J. Arid Environ., 58, 181-202, 2004.

Carlyle-Moses, D. E. and Price, A. G.: Growing-season stemflow production within a deciduous forest of southern Ontario, Hydrol. Process., 20, 3651-3663, 2006.

Carlyle-Moses, D. E. and Schooling, J.: Tree traits and meteorological factors influencing the initiation and rate of stemflow from isolated deciduous trees, Hydrol. Process., 29, 4083-4099, 2015.

Chao, P. N. and Gong, G. T.: Salix (Salicaceae), in: Flora of China, edited by: Wu, Z. Y., Raven, P. H., and Hong, D. Y., Science Press, Beijing and Missouri Botanical Garden Press, St. Louis, 162-274, 1999.

Clements, J. R.: Stemflow in a Multi-storied Aspen Community, Can. J. Forest. Res., 2, 160-165, 1972.

Crockford, R. H. and Richardson, D. P.: Partitioning of rainfall into throughfall, stemflow and interception: effect of forest type, ground cover and climate, Hydrol. Process., 14, 2903-2920, 2000.

Cui, M. Y. and Caldwell, M. M.: A large ephemeral release of nitrogen upon wetting of dry soil and corresponding root responses in the field, Plant Soil, 191, 291-299, 1997.

Deguchi, A., Hattori, S., and Park, H. T.: The influence of seasonal changes in canopy structure on interception loss: Application of the revised Gash model, J. Hydrol., 318, 80-102, 2006. 
Devitt, D. H. and Smith, S. D.: Root channel macropores enhance downward movement of water in a Mojave Desert ecosystem, J. Arid Environ., 50, 99-108, 2002.

Dolman, A. J.: Summer and winter rainfall interception in an oak forest. Predictions with an analytical and a numerical simulation model, J. Hydrol., 90, 1-9, 1987.

Dong, S. R., Guo, J. T., and Man, R. Z.: The throughfall, stemflow and interception loss of the Pinus tabuliformis plantations at northern China, J. Beijing Forest. Univ., 9, 58-68, 1987.

Dong, X. J. and Zhang, X. S.: Some observations of the adaptations of sandy shrubs to the arid environment in the Mu Us Sandland: leaf water relations and anatomic features, J. Arid Environ., 48, 41-48, 2001.

Dunkerley, D.: Measuring interception loss and canopy storage in dryland vegetation: a brief review and evaluation of available research strategies, Hydrol. Process., 14, 669-678, 2000.

Dunkerley, D.: Stemflow production and intrastorm rainfall intensity variation: an experimental analysis using laboratory rainfall simulation, Earth Surf. Proc. Land., 39, 1741-1752, 2014a.

Dunkerley, D.: Stemflow on the woody parts of plants: dependence on rainfall intensity and event profile from laboratory simulations, Hydrol. Process., 28, 5469-5482, 2014b.

Durocher, M. D.: Monitoring spatial variability of forest interception, Hydrol. Process., 4, 215-229, 1990.

Dykes, A. P.: Rainfall interception from a lowland tropical rainforest in Brunei, J. Hydrol., 200, 1-4, 1997.

Firn, R.: Plant Intelligence: an Alternative Point of View, Ann. Bot., 93, 345-351, 2004.

Garcia-Estringana, P., Alonso-Blazquez, N., and Alegre, J.: Water storage capacity, stemflow and water funneling in Mediterranean shrubs, J. Hydrol., 389, 363-372, 2010.

Germer, S., Elsenbeer, H., and Moraes, J. M.: Throughfall and temporal trends of rainfall redistribution in an open tropical rainforest, south-western Amazonia (Rondônia, Brazil), Hydrol. Earth Syst. Sci., 10, 383-393, doi:10.5194/hess-10-383-2006, 2006.

Giacomin, A. and Trucchi, P.: Rainfall interception in a beech coppice (Acquerino, Italy), J. Hydrol., 137, 141-147, 1992.

Groisman, P. Y. and Legates, D. R.: The accuracy of United States precipitation data, B. Am. Meteorol. Soc., 75, 215-227, 1994.

Gunn, R. and Kiner, G. D.: The Terminal Fall Velocity for Water Droplets in Stagnant Air, J. Atmos. Sci., 6, 243-248, 1949.

Hagy, A., Rajkai, K., and Nagy, Z.: Effect of forest and grassland vegetation on soil hydrology in Mátra Mountains (Hungary), Biologia, 61, S261-S265, 2006.

Herwitz, S. R.: Infiltration-excess caused by Stemflow in a cycloneprone tropical rainforest, Earth Surf. Proc. Land., 11, 401-412, 1986.

Herwitz, S. R.: Rainfall totals in relation to solute inputs along an exceptionally wet altitudinal transect, Catena, 14, 25-30, 1987.

Herwitz, S. R. and Slye, R. E.: Three-dimensional modeling of canopy tree interception of wind-driven rainfall, J. Hydrol., 168, $1-4,1995$

Honda, E. A., Mendonça, A. H., and Durigan, G.: Factors affecting the stemflow of trees in the Brazilian cerrado, Ecohydrology, 8, 1351-1362, 2015.

Jia, X. X., Shao, M. A., Wei, X. R., Horton, R., and Li, X. Z.: Estimating total net primary productivity of managed grasslands by a state-space modeling approach in a small catchment on the Loess Plateau, China, Geoderma, 160, 281-291, 2011.
Jia, X. X., Shao, M. A., Wei, X. R., and Wang, Y. Q.: Hillslope scale temporal stability of soil water storage in diverse soil layers, J. Hydrol., 498, 254-264, 2013.

Jian, S. Q., Zhao, C. Y., Fang, S. M., and Kai, Y. U.: Characteristics of Caragana korshinskii and Hippophae rhamnoides stemflow and their significance in soil moisture enhancement in Loess Plateau, China, J. Arid Land., 6, 105-116, 2014.

Johnson, M. S. and Lehmann, J.: Double-funneling of trees: Stemflow and root-induced preferential flow, Ecoscience, 13, 324333, 2006.

Jonard, M., Andre, F., and Ponette, Q.: Modeling leaf dispersal in mixed hardwood forests using a ballistic approach, Ecology, 87, 2306-2318, 2006.

Laws, J. O. and Parsons, D. A.: The relation of raindrop-size to intensity, Eos T. Am. Geophys. Un, 24, 452-460, 1943.

Levia, D. F. and Frost, E. E.: A review and evaluation of stemflow literature in the hydrologic and biogeochemical cycles of forested and agricultural ecosystems, J. Hydrol., 274, 1-29, 2003.

Levia, D. F. and Herwitz, S. R.: Interspecific variation of bark water storage capacity of three deciduous tree species in relation to stemflow yield and solute flux to forest soils, Catena, 64, 117137, 2005.

Levia, D. F. and Underwood, S. J.: Snowmelt induced stemflow in northern hardwood forests: a theoretical explanation on the causation of a neglected hydrological process, Adv. Water Resour., 27, 121-128, 2004.

Levia, D. F., Michalzik, B., Näthe, K., Bischoff, S., Richter, S., and Legates, D. R.: Differential stemflow yield from European beech saplings: the role of individual canopy structure metrics, Hydrol. Process., 29, 43-51, 2015.

Li, L., Li, X. Y., Zhang, S. Y., Jiang, Z. Y., Zheng, X. R., Hu, X., and Huang, Y. M.: Stemflow and its controlling factors in the subshrub Artemisia ordosica during two contrasting growth stages in the Mu Us sandy land of northern China, Hydrol. Res., 47, 409-418, 2015.

Li, X., Xiao, Q., Niu, J., Dymond, S., van Doorn, N. S., Yu, X., Xie, B., Lv, X., Zhang, K., and Li, J.: Process-based rainfall interception by small trees in Northern China: The effect of rainfall traits and crown structure characteristics, Agr. Forest Meteorol., 218-219, 65-73, 2016.

Li, X. Y.: Hydrology and Biogeochemistry of Semiarid and Arid Regions, in: Forest Hydrology and Biogeochemistry, edited by: Levia, D. F., Carlyle-Moses, D., and Tanaka, T., Springer, Netherlands, 285-299, 2011.

Li, X. Y., Liu, L. Y., Gao, S. Y., Ma, Y. J., and Yang, Z. P.: Stemflow in three shrubs and its effect on soil water enhancement in semiarid loess region of China, Agr. Forest Meteorol., 148, 15011507, 2008.

Li, X.-Y., Yang, Z.-P., Li, Y.-T., and Lin, H.: Connecting ecohydrology and hydropedology in desert shrubs: stemflow as a source of preferential flow in soils, Hydrol. Earth Syst. Sci., 13, 1133 1144, doi:10.5194/hess-13-1133-2009, 2009.

Li, X. Y., Hu, X., Zhang, Z. H., Peng, H. Y., Zhang, S. Y., Li, G. Y., Li, L., and Ma, Y. J.: Shrub hydropedology: preferential water availability to deep soil layer, Vadose Zone J., 12, doi:10.2136/vzj2013.01.0006, 2013. 
Liang, W. L., Kosugi, K. I., and Mizuyama, T.: Characteristics of stemflow for tall stewartia (Stewartia monadelpha) growing on a hillslope, J. Hydrol., 378, 168-178, 2009.

Liu, Y. X., Chang, Z. Y., and Gennady, P. Y.: Caragana (Fabaceae), in: Flora of China, edited by: Wu, Z. Y., Raven, P. H., and Hong, D. Y., Science Press, Beijing and Missouri Botanical Garden Press, St. Louis, 528-545, 2010.

Llorens, P. and Domingo, F.: Rainfall partitioning by vegetation under Mediterranean conditions. A review of studies in Europe, J. Hydrol., 335, 37-54, 2007.

Ma, C. C., Gao, Y. B., Wang, J. L., and Guo, H. Y.: Ecological adaptation of Caragana opulens on the Inner Mongolia Plateau: photosynthesis and water metabolism, Chinese J. Plant Ecol., 28, 305-312, 2004.

Ma, C. C., Gao, Y. B., Guo, H. Y., Wang, J. L., Wu, J. B., and Xu, J. S.: Physiological adaptations of four dominant Caragana species in the desert region of the Inner Mongolia Plateau, J. Arid Environ., 72, 247-254, 2008.

Martinez-Meza, E. and Whitford, W. G.: Stemflow, throughfall and channelization of stemflow by roots in three Chihuahuan desert shrubs, J. Arid Environ., 32, 271-287, 1996.

Masukata, H., Ando, M., and Ogawa, H.: Throughfall, stemflow and interception of rainwater in an evergreen broadleaved forest, Ecol. Res., 5, 303-316, 1990.

Mauchamp, A. and Janeau, J. L.: Water funnelling by the crown of Flourensia cernua, a Chihuahuan Desert shrub, J. Arid Environ., 25, 299-306, 1993.

Mcclain, M. E., Boyer, E. W., Dent, C. L., Gergel, S. E., Grimm, N. B., Groffman, P. M., Hart, S. C., Harvey, J. W., Johnston, C. A., and Mayorga, E.: Biogeochemical Hot Spots and Hot Moments at the Interface of Terrestrial and Aquatic Ecosystems, Ecosystems, 6, 301-312, 2003.

Murakami, S.: Abrupt changes in annual stemflow with growth in a young stand of Japanese cypress, Hydrol. Res. Lett., 3, 32-35, 2009.

Mużyło, A., Llorens, P., and Domingo, F.: Rainfall partitioning in a deciduous forest plot in leafed and leafless periods, Ecohydrology, 5, 759-767, 2012.

Návar, J.: Stemflow variation in Mexico's northeastern forest communities: Its contribution to soil moisture content and aquifer recharge, J. Hydrol., 408, 35-42, 2011.

Návar, J. and Bryan, R.: Interception loss and rainfall redistribution by three semi-arid growing shrubs in northeastern Mexico, J. Hydrol., 115, 51-63, 1990.

Neal, C., Robson, A. J., Bhardwaj, C. L., Conway, T., Jeffery, H. A., Neal, M., Ryland, G. P., Smith, C. J., and Walls, J.: Relationships between precipitation, stemflow and throughfall for a lowland beech plantation, Black Wood, Hampshire, southern England: findings on interception at a forest edge and the effects of storm damage, J. Hydrol., 146, 221-233, 1993.

O'Brien, R. M.: A Caution Regarding Rules of Thumb for Variance Inflation Factors, Qual. Quant., 41, 673-690, 2007.

Owens, M. K., Lyons, R. K., and Alejandro, C. L.: Rainfall partitioning within semiarid juniper communities: effects of event size and canopy cover, Hydrol. Process., 20, 3179-3189, 2006.

Pressland, A.: Rainfall partitioning by an arid woodland (Acacia aneura F. Muell.) in south-western Queensland, Aust. J. Bot., 21, 235-245, 1973.
Pypker, T. G., Levia, D. F., Staelens, J., and Van Stan II, J. T.: Canopy structure in relation to hydrological and biogeochemical fluxes, in: Forest Hydrology and Biogeochemistry, Springer, Netherlands, 371-388, 2011.

Rango, A., Tartowski, S. L., Laliberte, A., Wainwright, J., and Parsons, A.: Islands of hydrologically enhanced biotic productivity in natural and managed arid ecosystems, J. Arid Environ., 65, 235-252, 2006.

Reynolds, J. F., Virginia, R. A., Kemp, P. R., de Soyza, A. G., and Tremmel, D. C.: Impact of drought on desert shrubs: effects of seasonality and degree of resource island development, Ecol. Monogr., 69, 69-106, 1999.

Roth-Nebelsick, A., Ebner, M., Miranda, T., Gottschalk, V., Voigt, D., Gorb, S., Stegmaier, T., Sarsour, J., Linke, M., and Konrad, W.: Leaf surface structures enable the endemic Namib desert grass Stipagrostis sabulicola to irrigate itself with fog water, J. R. Soc. Interface, 9, 1965-1974, 2012.

Schwinning, S., Starr, B., and Ehleringer, J. R.: Dominant cold desert plants do not partition warm season precipitation by event size, Oecologia, 136, 250-260, 2003.

Sellin, A., Õunapuu, E., Kaurilind, E., and Alber, M.: Sizedependent variability of leaf and shoot hydraulic conductance in silver birch, Trees, 26, 821-831, 2012.

Siegert, C. M. and Levia, D. F.: Seasonal and meteorological effects on differential stemflow funneling ratios for two deciduous tree species, J. Hydrol., 519, 446-454, 2014.

Siles, P., Harmand, J.-M., and Vaast, P.: Effects of Inga densiflora on the microclimate of coffee (Coffea arabica L.) and overall biomass under optimal growing conditions in Costa Rica, Agroforest Syst., 78, 269-286, 2010a.

Siles, P., Vaast, P., Dreyer, E., and Harmand, J.-M.: Rainfall partitioning into throughfall, stemflow and interception loss in a coffee (Coffea arabica L.) monoculture compared to an agroforestry system with Inga densiflora, J. Hydrol., 395, 39-48, 2010 b.

Sponseller, R. A.: Precipitation pulses and soil $\mathrm{CO}_{2}$ flux in a Sonoran Desert ecosystem, Global Change Biol., 13, 426-436, 2007.

Stephenson, N. L., Das, A. J., Condit, R., Russo, S. E., Baker, P. J., Beckman, N. G., Coomes, D. A., Lines, E. R., Morris, W. K., Ruger, N., Alvarez, E., Blundo, C., Bunyavejchewin, S., Chuyong, G., Davies, S. J., Duque, A., Ewango, C. N., Flores, O., Franklin, J. F., Grau, H. R., Hao, Z., Harmon, M. E., Hubbell, S. P., Kenfack, D., Lin, Y., Makana, J. R., Malizia, A., Malizia, L. R., Pabst, R. J., Pongpattananurak, N., Su, S. H., Sun, I. F., Tan, S., Thomas, D., van Mantgem, P. J., Wang, X., Wiser, S. K., and Zavala, M. A.: Rate of tree carbon accumulation increases continuously with tree size, Nature, 507, 90-93, 2014.

Van Stan II, J., Siegert, C. M., Levia Jr., D. F., and Scheick, C. E.: Effects of wind-driven rainfall on stemflow generation between codominant tree species with differing crown characteristics, Agr. Forest Meteorol., 151, 1277-1286, 2011.

Van Stan II, J., Van Stan, J. H., and Levia Jr., D. F.: Meteorological influences on stemflow generation across diameter size classes of two morphologically distinct deciduous species, Int. J. Biometeorol., 58, 2059-2069, 2014.

Wang, X. P., Zhang, Y. F., Wang, Z. N., Pan, Y. X., Hu, R., Li, X. J., and Zhang, H.: Influence of shrub canopy morphology and rainfall characteristics on stemflow within a revegetated sand dune in the Tengger Desert, NW China, Hydrol. Process., 27, 1501$1509,2013$. 
Wang, X.-P., Wang, Z.-N., Berndtsson, R., Zhang, Y.-F., and Pan, Y.-X.: Desert shrub stemflow and its significance in soil moisture replenishment, Hydrol. Earth Syst. Sci., 15, 561-567, doi:10.5194/hess-15-561-2011, 2011.

Whitford, W. G., Anderson, J., and Rice, P. M.: Stemflow contribution to the 'fertile island' effect in creosotebush, Larrea tridentata, J. Arid Environ., 35, 451-457, 1997.

Wright, I. R.: Net rainfall below the forest canopy. Plynlimon throughfall-troughs and stemflow gauges, in: Selected Measurement Techniques in Use at Plynlimon Experimental Catchments, Inst. of Hydrol., Rep. 43, Wallingford, Oxon, 1977.

$\mathrm{Xu}, \mathrm{X}$., Wang, Q., and Hirata, E.: Precipitation partitioning and related nutrient fluxes in a subtropical forest in Okinawa, Japan, Ann. Forest Sci., 62, 245-252, 2005.

Yang, Z., Li, X., Liu, L., Wu, J., Hasi, E., and Sun, Y.: Characteristics of stemflow for sand-fixed shrubs in Mu Us sandy land, Northwest China, Chin. Sci. Bull., 53, 2207-2214, 2008.

Yang, Z. P.: Rainfall partitioning process and its effects on soil hydrological processes for sand-fixed shrubs in Mu Us sandland, northwest China, D. Sc., Beijing Normal University, Beijing, 2010 .
Yuan, C., Gao, G. Y., and Fu, B. J.: Stemflow of a xerophytic shrub (Salix psammophila) in northern China: Implication for beneficial branch architecture to produce stemflow, J. Hydrol., 539, 577-588, 2016.

Zhang, S. Y., Li, X. Y., Li, L., Huang, Y. M., Zhao, G. Q., and Chen, H. Y.: The measurement and modelling of stemflow in an alpine Myricaria squamosa community, Hydrol. Process., 29, 889-899, 2015.

Zhang, Z. S., Zhao, Y., Li, X. R., Huang, L., and Tan, H. J.: Gross rainfall amount and maximum rainfall intensity in 60-minute influence on interception loss of shrubs: a 10-year observation in the Tengger Desert, Sci. Rep., 6, 26030, doi:10.1038/srep26030, 2016.

Zhao, P. P., Shao, M. A., and Wang, T. J.: Spatial distributions of soil surface-layer saturated hydraulic conductivity and controlling factors on dam farmlands, Water Resour. Manage., 24, 2247-2266, 2010.

Zhu, Y. J. and Shao, M. A.: Variability and pattern of surface moisture on a small-scale hillslope in Liudaogou catchment on the northern Loess Plateau of China, Geoderma, 147, 185-191, 2008. 